\title{
islam nukantana
}

\section{Journal for Study of Islamic History and Culture}

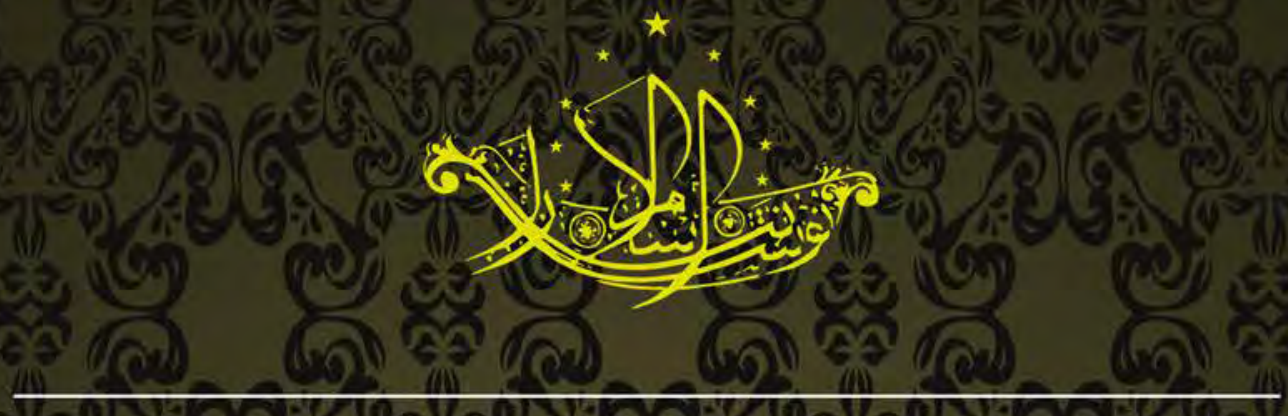

Pengantar Nomor Perdana - Nahdlatul Islam Nusantara Ahmad Suaedy

Anatomy of the Islam Nusantara Program and the Necessity for a "Critical" Islam Nusantara Study

Okamoto Masaaki:

Artikulasi Islam Nusantara dalam Perjuangan Agraria
Menuju Sosiologi Nusantara: Analisa Sosiologis Ajaran
Ki Ageng Suryomentaram dan Amanat Galunggung
Traditional Islam and Global Religious Connectivity:
Nahdlatulumama in The Netherlands)

Lasem: Harmoni dan Kontestasi Masyarakat Bineka Syamsul Hadi

Traces of Mäturidism in the 'Ulamäs Works in Nusantara in the Seventeenth Until Nineteenth Centuries

\section{Book Review}

Islam Dibawa Masuk oleh Orang Nusantara: Dari Data Terserak

Buzurgh Al-Ramahurmuzi, 'Ajaibul Hind: Kisah-Kisah Ajaib di Daratan dan Lautan Hindi

Idris Masudi 



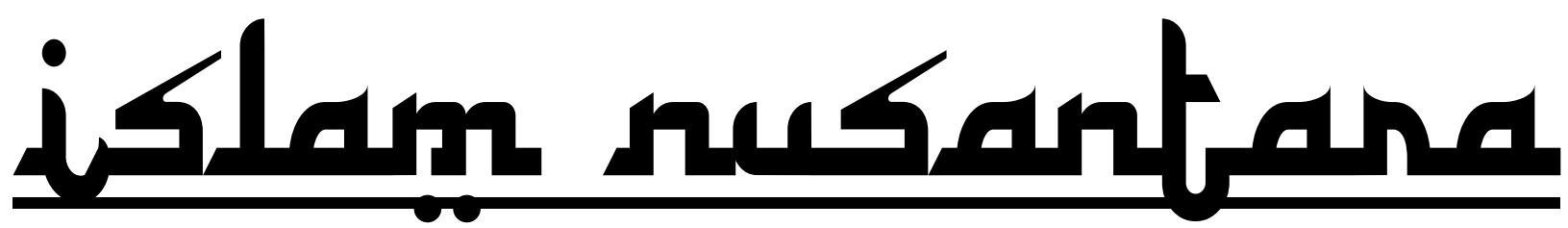

Journal for Study of Islamic History and Culture

Pengantar Nomor Perdana - Nahdlatul Islam Nusantara

Ahmad Suaedy

Anatomy of the Islam Nusantara Program and the Necessity for a

“Critical” Islam Nusantara Study

Okamoto Masaaki

Artikulasi Islam Nusantara dalam Perjuangan Agraria

Mohamad Shohibuddin

Menuju Sosiologi Nusantara: Analisa Sosiologis Ajaran

Ki Ageng Suryomentaram dan Amanat Galunggung

Ngatawi El-Zastrouw

Traditional Islam and Global Religious Connectivity:

Nahdlatul Ulama in The Netherlands

Amin Mudzakkir

Lasem: Harmoni dan Kontestasi Masyarakat Bineka

Syamsul Hadi

Traces of Māturīdīsm in the 'Ulamā's Works in Nusantara in the Seventeenth Until Nineteenth Centuries

Muhamad Bindaniji

Book Review

Islam Dibawa Masuk oleh Orang Nusantara: Dari Data Terserak

Buzurgh Al-Ramahurmuzi, 'Ajaibul Hind: Kisah-Kisah Ajaib

di Daratan dan Lautan Hindi

Idris Masudi 


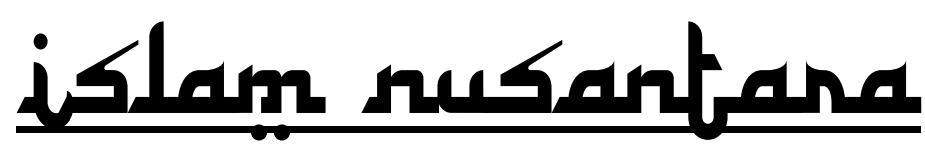

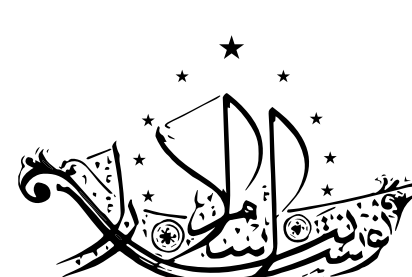




\section{islam rusantane}

Journal for Study of Islamic History and Culture

Volume I, Number I, July 2020

\section{EDITOR-IN-CHIEF}

Ahmad Suaedy, (Scopus ID: 56419869500) Faculty of Islam Nusantara UNUSIA Jakarta

\section{MANAGING EDITOR}

Ngatawi El-Zastrow, Faculty of Islam Nusantara UNUSIA Jakarta

INTERNATIONAL EDITORIAL BOARD

Said Aqil Siradj, Faculty of Islam Nusantara UNUSIA Jakarta

Robert W. Hefner, (Scopus ID: 36856758800) Boston University, Boston USA

Okamoto Masaaki, (Scopus ID: 57191206120), Kyoto University, Kyoto Japan

Dien Madjid, Universitas Islam Negeri Syarif Hidayatullah, Jakarta

Endang Turmudzi, Lembaga Ilmu Pengetahuan Indonesia (LIPI)

Alwi A. Shihab, Indonesian Muslim Intellectual and expert on Middle East Studies and Muslim Civilization

James Bourk Hoesterey, Emory University, Atlanta GA, USA

Hisanori Kato, (Scopus ID: 55996362300), Chuo University, Tokyo Japan

Abdul Moqsith, Universitas Islam Negeri Syarif Hidayatullah, Jakarta

Sahiron Syamsuddin, (Scopus ID: 55996362300) Universitas Islam Negeri Sunan Kalijaga,

Yogyakarta

Muhammad Ishom, Universitas Islam Negeri Sultan Maulana Hasanuddin, Banten

Azhar Ibrahim, (Scopus ID: 7202979037) National University of Singapore, Singapore

\section{ADVISORY EDITORS}

Hamdani, Faculty of Islam Nusantara UNUSIA Jakarta

\section{EDITORIAL BOARD}

Maria Ulfah, Faculty of Islam Nusantara UNUSIA Jakarta

Ulil Abshar Abdalla, Faculty of Islam Nusantara UNUSIA Jakarta

Syamsul Hadi, Faculty of Islam Nusantara UNUSIA Jakarta

Ali Abdillah, Faculty of Islam Nusantara UNUSIA Jakarta

Ayatullah, Faculty of Islam Nusantara UNUSIA Jakarta

Ulil Abshar, Universitas Islam Negeri Syarif Hidayatullah, Jakarta

Ahmad Ginandjar Sya'ban, Faculty of Islam Nusantara UNUSIA Jakarta

Idris Masudi, Faculty of Islam Nusantara UNUSIA Jakarta 
ISLAM NUSANTARA: Journal for Study of Islamic History and Culture facilitates the publication of article and book review on study of Islam, Muslim culture, social, politics and history in Southeast Asia (Nusantara) and beyond. It is published twice a year and written in Indonesia, English and Arabic. It aims to present academic insight of social and cultural complexity of Muslim world in Southeast Asia under the frame of dialectic between Islam and local culture or cultural realities.

The journal invites scholars and experts working in various disciplines in Islamic studies, humanities, and social sciences. Articles should be original, researchbased, unpublished and not under review for possible publication in other journals. All submitted papers are subject to a review of the editors, editorial board, and blind reviewers.

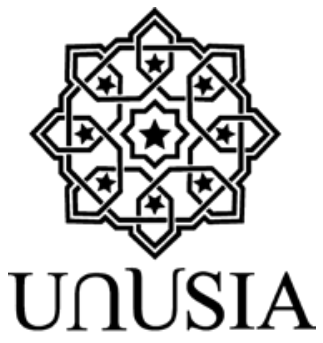

EDITORIAL JOURNAL

Gedung Kampus UNUSIA Lantai 2

Jl. Taman Amir Hamzah No. 5 Jakarta Pusat 10430

E-mail : Islamnusantarajournal@unusia.ac.id or Journalofislamnusantara@gmail.com

Website : http://journal.unusia.ac.id/index.php/ ISLAMNUSANTARA/about 


\section{Table of Contents}

\section{Articles}

$1 \quad$ Ahmad Suaedy

Pengantar Nomor Perdana - Nahdlatul Islam Nusantara

13 Okamoto Masaaki

Anatomy of the Islam Nusantara Program and the

Necessity for a "Critical" Islam Nusantara Study

41 Mohamad Shohibuddin

Artikulasi Islam Nusantara dalam Perjuangan Agraria

89 Ngatawi El-Zastrouw

Menuju Sosiologi Nusantara: Analisa Sosiologis Ajaran

Ki Ageng Suryomentaram dan Amanat Galunggung

145 Amin Mudzakkir

Traditional Islam and Global Religious Connectivity:

Nahdlatul Ulama in The Netherlands

163 Syamsul Hadi

Lasem: Harmoni dan Kontestasi Masyarakat Bineka

209 Muhamad Bindaniji

Traces of Māturīdīsm in the 'Ulamā’s Works in Nusantara in the Seventeenth Until Nineteenth Centuries

\section{Book Review}

239 Idris Masudi

Islam Dibawa Masuk oleh Orang Nusantara: Dari Data Terserak Buzurgh Al-Ramahurmuzi, 'Ajaibul Hind: Kisah-Kisah Ajaib di Daratan dan Lautan Hindi 


\title{
Artikulasi Islam Nusantara Dalam Perjuangan Agraria
}

Fakultas Ekologi Manusia, Institut Pertanian Bogor m-shohib@apps.ipb.ac.id

\begin{abstract}
This article focuses on a specific topics rarely discussed in the scholarship of Islam Nusantara, namely the contribution of Islam Nusantara in addressing agrarian problems experienced by the community. To reveal such contribution, the author proposes the perspective of "access and exclusion" as a theoretical framework for understanding the nature of social struggle in the agrarian field. Based on this, the author will disclose the contribution of Islam Nusantara in "pursuing access" and at the same token "preventing exclusion" within various situations of agrarian struggle, starting from the family level (as concerned with inheritance system and joint marital property) to broader level of socioagrarian relations (as related to inequalities in land tenure, relations of production and spatial allocation). In addition, the author will examines "agrarian ijtihad" issued by Nahdlatul Ulama and also proposes the idea of "agrarian waqf"-both constitute religious responses to "challenges of
\end{abstract}

1 Artikel ini merupakan pengembangan dari presentasi yang penulis sampaikan pada Simposium Nasional "Islam Nusantara dan Tantangan Global," diselenggarakan oleh Universitas Nahdlatul Ulama Indonesia (UNUSIA) di Gedung PBNU, Jakarta, 8 Februari 2020. 
access" and "threats of exclusion" taking place within the community.

Keywords: Islam Nusantara, struggle for access; struggle against exclusion; agrarian ijtihad; Nahdlatul Ulama; agrarian waqf

Abstrak: Tulisan ini mengangkat satu topik kajian yang jarang diperhatikan dalam kesarjanaan Islam Nusantara yang berkembang pesat dewasa ini, yaitu kontribusi Islam Nusantara pada pergulatan agraria yang dihadapi masyarakat. Untuk mengungkapkan kontribusi ini, penulis menawarkan perspektif "dialektika akses dan eksklusi” sebagai kerangka teoritis untuk memahami inti pergulatan sosial dalam bidang agraria. Dari sini penulis akan memperlihatkan kontribusi Islam Nusantara dalam "mengupayakan akses" dan sekaligus "mencegah eksklusi" pada aneka situasi pergulatan agraria yang dialami masyarakat, mulai dari level keluarga (seperti menyangkut harta waris atau harta pencaharian bersama) hingga level relasi sosio-agraria yang lebih luas lagi (seperti menyangkut ketimpangan agraria, relasi produksi dan alokasi ruang). Selain menyajikan tiga kasus di level keluarga dan dua kasus yang lebih umum di level masyarakat, penulis secara khusus juga mengulas “ijtihad agraria” yang dikeluarkan Nahdlatul Ulama dan sekaligus menawarkan gagasan mengenai "wakaf agraria”-keduanya sebagai respons keagamaan atas tantangan akses dan ancaman eksklusi yang berlangsung di tengah masyarakat.

Kata Kunci: Islam Nusantara; perjuangan akses; perjuangan kontraeksklusi; ijtihad agraria; Nahdlatul Ulama; wakaf agraria 
الملخص: يناقش هذا البحث موضوعا فريدا قلما ناقشوه الخبراء في مجال "إسلام نوسانتارا"، و هو جهود "إسلام نوسانتارا" في معالجـة بعض المشاكل الزراعية التي يواجهها المجتمع الإندونيسي. و في دراسـة هذا الجهود، يقوم الباحث باستعمال منهج "جدلية الوصول و الاستبعاد" كإطار نظري لفهم لب الحركة الإجتماعية في مجال الزراعة. و هنا، يعرض الباحث اسهامات "إسلام نوسانتارا" وجهوده في محاولة "فتح السبل" و "دفع الاستبعاد" في بعض مواقف الحركات الزراعية، بداء من مستوى العائلة (كالأمور المتعلقة بالأموال الوراثية و الأموال الكسبية) حتى مستوى العلاقة بين الاجتماع والزراعة بشكل أوسع (كالأمور المتعلقة بالفجوة الإجتماعية و عدم المساوة في حق التحكم على الأرض، أو العلاقة بين الانتاج و التصميم السكني أو التخطيط المكاني). كما أن الباحث سيناقش أيضا بـ"اجتهادات" جمعية نهضة العلماء بالأمور الزراعية واقتراح فكرة "الوقف

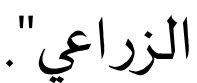

الكلمات الإرشادية: إسلام نوسانتارا، جهاد الوصول، جهاد ضد الاستبعاد، الاجتهاد الزراعي، هضية العلماء، الوقف الزراعي. 


\section{Pendahuluan}

I slam Nusantara, sebagai hasil dari dialog kreatif antara nilai dan ajaran universal Islam dengan konteks spesifik di wilayah Nusantara, semakin Hal ini terbukti dari publikasi ilmiah mengenai topik ini yang terus meningkat selama beberapa tahun terakhir. Di tengah perkembangan positif semacam ini, sayangnya, masih sedikit perhatian yang secara khusus ditujukan pada kontribusi Islam Nusantara dalam merespons berbagai persoalan agraria. Hal ini sangatlah mengherankan karena relasi-relasi sosial terkait penguasaan dan pemanfaatan tanah (baca: social relations of property) merupakan pergulatan yang selalu dialami masyarakat Nusantara. Dalam sejarahnya, pergulatan semacam ini bahkan telah melahirkan berbagai respons keagamaan yang genuine, baik dalam bentuk fatwa dari ulama dan organisasi Islam maupun kebijakan dari pemerintah.

Secara tipikal, respons keagamaan atas berbagai problem agraria semacam ini dapat dianggap sebagai artikulasi Islam Nusantara par excellence. Setidaknya, ada dua alasan utama yang bisa diajukan untuk mendukung pernyataan ini. Pertama, ditilik secara konseptual, respons keagamaan tersebut tidak terlepas dari karakter dasar Islam Nusantara itu sendiri yang memang memiliki kepedulian tinggi bukan saja pada agenda pribumisasi, akan tetapi pada saat yang sama juga agenda transformasi. Kedua, respons keagamaan itu secara faktual juga memperlihatkan upaya nyata untuk mengejawantahkan kedua agenda ini sebagai solusi atas berbagai pemasalahan agraria yang dihadapi oleh masyarakat di Nusantara. 
Merujuk Shohibuddin, ${ }^{2}$ konseptualisasi dua agenda Islam Nusantara di atas-yakni pribumisasi dan transformasi-secara normatif bertolak dari kualifikasi umat Islam sebagai "umat terbaik" (khayr ummah) dalam QS. Âlu 'Imrân/3: 110. Menurut ayat ini, selain ditentukan oleh keimanan kepada Allah SWT, "umat terbaik" juga dicirikan oleh kepedulian tinggi untuk mewujudkan al-ma'rûf dan sekaligus menghindarkan al-munkar.

Secara leksikal, apa yang disebut al-ma'rûf adalah "segala hal yang sudah dikenal luas", baik karena termasuk kebiasaan lokal yang dianggap baik, merupakan nilai-nilai kebaikan universal, atau mencermikan common sense. Sejalan dengan ini, kata al-ma'rûf kemudian dipahami sebagai konsep yang merujuk segala sesuatu yang diinsyafi dan diterima masyarakat sebagai kebajikan dan keutamaan karena sejalan dengan akal sehat, hati nurani, dan fitrah dasar kemanusiaan. ${ }^{3}$ Tidak heran jika istilah al-ma'rûf ini mempunyai keterkaitan semantik yang erat dengan istilah al-'urf dalam QS. Al-A'râf/7: 199 yang secara leksikal memiliki arti "kebiasaan atau adat istiadat yang baik". ${ }^{4}$

Pemahaman al-ma'rûf semacam inilah yang mengantarkan pada agenda pertama Islam Nusantara, pribumisasi, yakni upaya mendialogkan universalisme Islam dengan lokalitas Nusantara. Di sini penting dicatat dua bentuk translasi yang berlangsung secara intens selama proses kreatif pribumisasi ini, yakni apa yang penulis istilahkan sebagai "indijenisasi" dan "universalisasi". Dalam indijenisasi, terjadi suatu proses di mana pesan-pesan transendental dan moral Islam yang bersifat universal itu dibumikan di Nusantara dengan memanfaatkan (sekaligus memodifikasi) aneka konsep, simbol budaya, arsitektur, dan pranata sosial-politik yang

2 Mohamad Shohibuddin, "Dua Wajah Islam Nusantara," Koran Sindo, 11 April 2017.

3 Barangkali karena ini, QS. Âlu 'Imrân/3: 104 menyandingkan kata al-ma'rûf dengan kata al-khayr yang berarti "kebaikan".

4 Pada kenyataannya, kata al-urf memang berbagi akar kata yang sama dengan al-márûf, dan karena itu konsep al-'urf haruslah dipahami sebagai suatu bentuk institusionalisasi atau pelembagaan (tentunya, dalam konteks historis dan geografis yang spesifik) atas segala hal yang telah diterima luas sebagai kebaikan, keutamaan dan kepentingan bersama. 
telah ada, dikenal dan dipraktikkan secara luas oleh masyarakat. Dalam universalisasi, sebaliknya, terjadi proses yang berbalik arah, yakni dari partikularitas menuju universalitas. Proses ini merujuk kepada bagaimana nilai, norma sosial dan adat istiadat yang diterima sebagai kebajikan dan keutamaan di aras lokal (baca: al-urf) diangkat dan kemudian diadopsi menjadi bagian dari hukum Islam yang berlaku lebih luas (misalnya saja, di tingkat nasional) karena kesesuaiannya dengan spirit dan prinsip dasar Syariat Islam. Di sini berlaku satu ketentuan dalam yurisprudensi Islam: al-âdah muhakkamah (adat kebiasaan yang baik bisa dijadikan sebagai aturan hukum).

Agenda Islam Nusantara yang kedua, yakni transformasi, merupakan kepedulian yang tidak kalah penting. Sebagaimana diketahui, perintah Allah untuk mencegah dan menghindarkan al-munkar selalu mengiringi perintah-Nya untuk mewujudkan al-márûf. Pada kenyataannya, objek dua perintah Allah ini tidak terpisah satu sama lain sehingga pelaksanaan keduanya juga harus bersifat simultan. Apabila al-márûf berarti sesuatu yang telah diketahui dan diterima luas karena sejalan dengan akal sehat, hati nurani dan fitrah kemanusiaan, maka al-munkar adalah sesuatu yang justru diingkari secara luas karena ia menyalahi akal sehat, hati nurani dan fitrah kemanusiaan. Karena itu, tidak mungkin untuk mewujudkan al-márûf tanpa pada saat yang sama juga mencegah dan merombak almunkar. Atau dinyatakan secara berbeda, agenda pribumisasi belaka tidak akan berdampak nyata tanpa disertai dengan agenda transformasi. Hanya dengan kombinasi dua agenda inilah maka Islam Nusantara dapat benarbenar dirasakan keberadaannya sebagai kekuatan pembebasan.

Sepanjang sejarah Nusantara, kedua agenda di atas juga terus diupayakan perwujudannya oleh umat Islam, termasuk ketika berkaitan dengan isu agraria. Sebagai ilustrasi, bukankah adopsi sistem gono-gini di Jawa (atau sebutan lainnya di daerahlain) adalah responskeagamaan untuk melindungi hak istri atas harta perkawinan (marital property); suatu bentuk realisasi alma'rûf melalui "universalisasi" atas kebiasaan lokal yang baik dan diterima 
luas? Di sisi lain, bukankah perjuangan melawan penjajah yang digelorakan para ulama Nusantara adalah jihad melawan al-munkar, termasuk yang terwujud dalam bentuk kemungkaran agraria (seperti ditunjukkan oleh kasus Perang Diponegoro, misalnya) $?^{5}$

\section{Merambah Jalan Baru Islam Nusantara}

Sayangnya, meskipun memiliki banyak preseden historis seperti diilustrasikan secara sekilas di atas, namun kiprah dan kontribusi Islam Nusantara dalam memberikan respons atas berbagai persoalan agraria di tanah air ini justru tidak mendapatkan perhatian yang semestinya. Hal ini terjadi tidak saja di kalangan para sarjana dan peneliti Islam Nusantara, namun ironisnya juga dapat ditemukan pada sebagian eksponen Islam Nusantara itu sendiri.

Apabila pengabaian semacam ini tidak segera diluruskan, maka eksistensi Islam Nusantara di masa depan dikhawatirkan akan mengalami krisis relevansi. Sebab, di tengah rekonfigurasi kapitalisme global yang berlangsung dengan penuh kekerasan dewasa ini, masyarakat Indonesia dihadapkan pada persoalan agraria dan ekologi yang makin beragam, bertambah kompleks, dan berlangsung pada skala yang lebih luas dan massif. ${ }^{6}$ Sudah barang tentu, tantangan besar semacam ini menuntut respons keagamaan yang sepadan pula (selain respons dalam bentuk lainnya)_apabila relevansi Islam Nusantara memang hendak terus diwujudkan di seluruh penjuru tanah air.

Artikel ini dimaksudkan sebagai ikhtiar sederhana penulis untuk turut

5 Dalam konteks kontemporer, perjuangan melawan kemungkaran agraria ini dilakukan, sebagai misal, oleh Kiai Nur Aziz dan Sutrisno Rusmin di Kendal. Bersama para petani penggarap, keduanya menentang tindakan PT Sumurpitu Wringinsari yang melakukan tukar guling atas lahan HGU yang ditelantarkannya sejak 1970 kepada PT Semen Indonesia. Perlawanan ini membuat keduanya harus mendekam di sel penjara selama hampir dua tahun dan baru dibebaskan pada 13 Mei 2019 setelah mendapatkan grasi dari Presiden Joko Widodo berkat desakan dari PBNU dan kalangan gerakan agraria.

6 Untuk ilustrasi mengenai berbagai persoalan agraria dan ekologi kontemporer ini, lihat misalnya: Mohamad Shohibuddin dan Adi D. Bahri, ed. Perjuangan Keadilan Agraria, (Yogyakarta, Bogor, Jakarta dan Bandung: Insist Press bekerja sama dengan Sajogyo Institute, Bina Desa, Akatiga, 2019). 
menumbuhkembangkan jalan baru kajian dan sekaligus praksis Islam Nusantara yang sensitif terhadap permasalahan agraria dan ekologi yang terjadi di tanah air. Sebagai langkah rintisan, penulis akan menawarkan perspektif "dialektika akses dan eksklusi” sebagai sebuah kerangka teoritis untuk memahami inti dari pergulatan sosial di bidang agraria. Berdasarkan kerangka teoritis ini, penulis selanjutnya akan menelusuri kontribusi Islam Nusantara pada perjuangan agraria dalam berbagai ranahnya, baik menyangkut kiprah historisnya di masa lalu maupun peran yang dituntut untuk dimainkannya di masa kini.

Secara khusus, pertanyaan kunci yang akan menjadi pokok bahasan artikel ini adalah sebagai berikut:

Apa saja artikulasi Islam Nusantara dalam upayanya "menjamin akses" dan sekaligus "mencegah eksklusi" dalam berbagai situasi pergulatan agraria yang dihadapi oleh masyarakat?

Untuk mengelaborasi pertanyaan kunci di atas lebih lanjut, beberapa pertanyaan turunan sebagai berikut akan didiskusikan yang sekaligus akan memandu sistematika penulisan artikel ini.

1. Bagaimanakah artikulasi Islam Nusantara dalam merespons pergulatan agraria di level keluarga?

2. Pada ranah sosial yang lebih luas, bagaimana artikulasi Islam Nusantara, khususnya yang disuarakan secara kelembagaan oleh Nahdlatul Ulama, dalam merespons berbagai persoalan agraria yang dihadapi masyarakat?

3. Sejauh manakah skema wakaf dapat dikembangkan sebagai terobosan "ijtihad agraria” Islam Nusantara dalam rangka mengejawantahkan kedua agendanya secara simultan, yakni pribumisasi dan transformasi?

Sesuai rumusan tiga pertanyaan yang tersebut di atas, artikel ini akan mendiskusikan secara rinci respons-respons keagamaan seperti apakah yang telah diartikulasikan demi "mengupayakan akses" dan sekaligus "mencegah eksklusi” dalam pergulatan agraria yang dihadapi oleh masyarakat. Hal ini 
secara khusus akan ditelusuri mulai dari level keluarga (seperti menyangkut harta waris dan harta pencaharian bersama) hingga relasi sosio-agraria yang lebih luas di level masyarakat (misalnya terkait ketimpangan dalam penguasaan tanah, relasi produksi dan tata ruang). ${ }^{7}$

Berkenaan dengan respons keagamaan di ranah sosial yang lebih luas, "ijtihad agraria" yang dikeluarkan Nahdlatul Ulama akan dijadikan fokus artikel ini, baik dalam bentuk keputusan bahtsul masâil yang dikeluarkan forum pengambilan keputusan di pusat maupun dalam bentuk peran dan posisi NU di tengah pro dan kontra program land reform di era 1960-an. Terakhir, artikel ini juga mengusulkan gagasan "wakaf agraria" sebagai terobosan mewujudkan "ijtihad agraria” Islam Nusantara.

Namun, sebelum memulai pembahasan semua topik di atas, pada bagian berikut akan disajikan terlebih dahulu kerangka teoritis yang digunakan dalam artikel ini.

\section{Dialektika Akses dan Eksklusi}

Pada dasarnya, pergulatan agraria yang dihadapi oleh masyarakat tidak pernah lepas dari dialektika antara "kekuatan akses" di satu sisi dan "kekuatan eksklusi" di sisi lain. Kedua hal ini adalah ibarat sekeping koin yang salah satu sisinya tidak dapat dibayangkan tanpa keberadaan sisi lainnya. Begitulah, seperti dua sisi mata uang, akses dan eksklusi selalu ditemukan secara serentak pada setiap relasi sosial kepemilikan (social relations of property)-yang dalam konteks artikel ini berkaitan dengan penguasaan atas tanah dan sumber-sumber agraria lainnya (air, ruang angkasa, dan berbagai kekayaan alam yang dikandungnya).

Lantas, apa sebenarnya yang dimaksud dengan akses itu? Mengacu

7 Sebagai catatan, kendati fokus artikel ini adalah artikulasi Islam Nusantara, namun dalam uraian mengenai respons keagamaan atas pergulatan agraria di level keluarga dan ranah sosial yang lebih luas penulis juga akan merujuk kepada landasan normatif dan preseden historis pada masa Nabi Muhammad SAW dan para sahabat. Selain itu, pada bagian yang relevan, penulis juga akan melakukan perbandingan pada kasus-kasus di belahan dunia yang lain dalam rentang waktu yang berbeda-beda. 
Ribot dan Peluso, ${ }^{8}$ akses dapat didefinisikan sebagai "kemampuan (ability) menarik manfaat dari sesuatu (things)". Di sini, Ribot dan Peluso menekankan bahwa apa yang dapat membuat seseorang mampu menarik manfaat tertentu dari sesuatu tidaklah ditentukan semata-mata oleh hak legal yang dimilikinya. Alih-alih, kemampuan itu terutama ditentukan oleh "simpul-simpul kekuatan" (bundles of powers) yang lebih luas di mana hak legal hanya merupakan salah satu bentuknya semata.

Adapun pengertian dari "sesuatu" (things) yang menjadi sasaran untuk diambil manfaatnya ini dapat mencakup apa saja yang dianggap berharga. Ia dapat berupa materi (seperti harta benda), perorangan (seperti pemilik otoritas), institusi (seperti norma hukum agama), dan sebagainya. Dalam konteks artikel ini, "sesuatu" di sini bisa berupa benda-benda material seperti tanah, air, udara, hutan, mineral, karbon, dan sebagainya; atau berupa tokoh otoritatif dan pranata sosial-keagamaan yang terlibat (dilibatkan) dalam pergulatan memperoleh manfaat dari berbagai benda material tadi.

Mengingat kemampuan memperoleh manfaat dari sesuatu tidaklah given (sebaliknya, selalu bersifat relasional dalam kaitan dengan ragam "simpul kekuatan" yang tersedia), maka serentak dengan itu ia sekaligus dibayang-bayangi oleh hambatan atau kendala dari pasangan dialektisnya sendiri, yaitu eksklusi. ${ }^{9}$ Apa yang dimaksud dengan eksklusi di sini adalah "berbagai cara yang melaluinya seseorang dicegah untuk dapat memperoleh manfaat dari sesuatu." ${ }^{10}$ Seperti halnya pada kasus akses, maka di sini pun faktor-faktor yang menentukan terjadinya eksklusi adalah berbagai "simpul kekuatan" dalam arti luas dan tidak terbatas pada hak legal semata. Perbedaan di antara keduanya adalah: apabila pada kasus akses berbagai

8 Jesse C. Ribbot dan Nancy Lee Peluso, “A Theory of Access." Rural Sociology 68, No. 2 (2003): p. 154-155.

9 Mohamad Shohibuddin, Eko Cahyono, Adi Dzikrullah Bahri, "Undang-Undang Desa dan Isu Sumber Daya Alam: Peluang Akses atau Ancaman Eksklusi?” Wacana 19, No. 36 (2017): p. 37.

10 Derek Hall, Philip Hirsch, Tania Murray Li, Powers of Exclusion: Land Dilemmas in Southeast Asia, (Singapore: NUS Press, 2011), p. 7. 
simpul kekuatan tadi memampukan seseorang untuk menarik manfaat tertentu dari sesuatu, maka di sini berbagai simpul kekuatan tersebut justru menghalang-halangi yang bersangkutan dari menarik manfaat tertentu dari sesuatu. Atau singkatnya, membuat orang tersebut gagal mewujudkan akses.

Dalam kasus akses, berbagai simpul kekuatan yang menjadi faktor penentu itu dapat dipilah menjadi tiga kategori sebagai berikut. Pertama adalah kekuatan dalam bentuk hak-hak legal, seperti akses yang didasarkan pada hukum agama, hukum adat, dan undang-undang. Kedua adalah kekuatan dalam bentuk berbagai mekanisme ilegal, misalnya seseorang menggunakan kedudukan politiknya untuk mewujudkan akses, kendati secara legal ia tidak memiliki hak sama sekali terhadapnya. Ketiga adalah kekuatan berupa berbagai mekanisme struktural dan relasional yang bentuknya lebih beragam, misalnya penguasaan dan/atau pengendalian atas berbagai faktor berikut: teknologi, modal, pasar, tenaga kerja, pengetahuan, otoritas, jaringan berbasis identitas, dan sebagainya. ${ }^{11}$

Demikian pula, terdapat sejumlah simpul kekuatan yang menyebabkan proses eksklusi terjadi. Secara umum, hal ini dapat dikelompokkan menjadi empat kategori sebagai berikut. Pertama adalah regulasi, misalnya saja peraturan yang dibuat oleh pemerintah yang lebih memfasilitasi pemilik modal besar memperoleh kemudahan berusaha dan lahan luas, ${ }^{12}$ sementara di sisi lain pemerintah justru mempersulit prosedur pelaksanaan program redistribusi tanah untuk rakyat. Kedua adalah paksaan (force), yakni eksklusi dengan cara penggunaan kekerasan atau ancaman penggunaan kekerasan. Ketiga adalah pasar sebagai faktor yang dapat membatasi akses melalui mekanisme harga dan insentif ekonomi lainnya. Keempat adalah legitimasi yang menciptakan landasan moral untuk memaksakan klaimklaim yang bersifat eksklusif, termasuk menjadikan proses eksklusi melalui

11 Jesse C. Ribbot dan Nancy Lee Peluso, "A Theory of Access."

12 Contohnya adalah RUU Cipta Kerja yang saat penulisan artikel ini sedang digenjot proses legislasinya di DPR di tengah gelombang penolakan masyarakat luas, termasuk PBNU dan PP Muhammadiyah. 
tiga kekuatan sebelumnya sebagai sesuatu yang bisa diterima secara politik dan sosial. ${ }^{13}$

Dalam Gambar 1 berikut ini dirangkum berbagai kekuatan akses dan eksklusi di atas serta keterkaitan timbal baliknya satu sama lain.

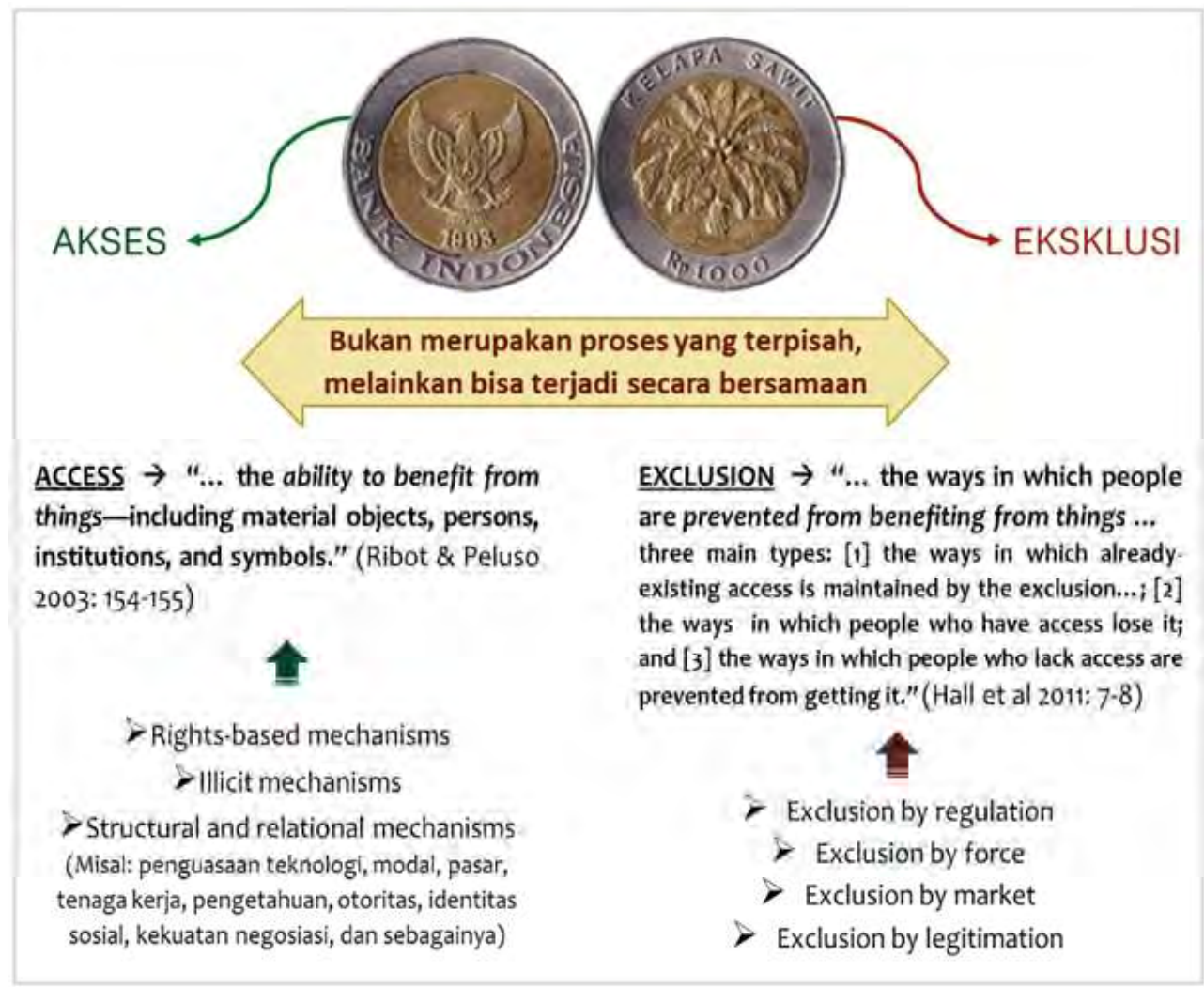

\section{Gambar 1. Dialektika Akses dan Eksklusi serta Berbagai Simpul Kekuatan yang Membentuknya}

Seperti telah dikemukakan, dua proses akses dan eksklusi ini tidaklah bersifat berurutan (sekuensial), namun berlangsung serentak pada saat yang bersamaan. ${ }^{14}$ Sebagai contoh, agar akses atas tanah bisa diperoleh, dipertahankan, ataupun diakumulasi, maka seseorang akan menjalankan eksklusi terhadap pihak lain. Jadi, ketika akses atas tanah dapat diwujudkan oleh satu pihak, maka pada saat yang sama ada pihak lain yang aksesnya menjadi tertutup, berkurang atau bahkan lenyap sama sekali.

13 Derek Hall, Philip Hirsch, Tania Murray Li, Powers of Exclusion, p. 4-5.

14 Cf. Mohamad Shohibuddin, Eko Cahyono, Adi Dzikrullah Bahri, "Undang-Undang Desa dan Isu Sumber Daya Alam.” 
Contoh lain adalah proses eksklusi yang terjadi melalui suatu program yang justru pada awalnya ditujukan untuk mewujudkan akses. Karena desain dan prosedur pelaksanaan program tersebut sedemikian rumit dan berbelit-belit, maka beberapa orang yang berhak justru tersisih dari peluang menjadi penerima manfaat. Di sinilah terletak arti "dialektika akses dan eksklusi"; yaitu bahwa dua proses ini selalu hadir pada semua relasi sosial, termasuk di seputar "persoalan-persoalan agraria".

Mengenai apa yang dimaksud dengan "persoalan agraria" di sini, secara umum ia dapat dibedakan menjadi empat kategori berikut. Pertama adalah persoalan ketidakpastian/kerentanan (insecurity) dalam penguasaan dan pemilikan sumber-sumber agraria (SSA). Kedua adalah persoalan ketimpangan (inequality) dalam penguasaan dan pemilikan SSA. Ketiga adalah persoalan ketidakadilan (unfairness) dalam relasi produksi dan distribusi surplus. Dan terakhir adalah persoalan ketidakserasian pada aras bentang alam yanglebih luas, yaitu mengenai ketidakpastian, ketidaksesuaian dan ketimpangan dalam penataan ruang dan pemanfaatan SSA yang pada gilirannya akan berdampak buruk pada kondisi ekologi. ${ }^{15}$

Bertolak dari perspektif teoritis di atas, artikel ini lebih lanjut akan membahas berbagai situasi pergulatan agraria yang terjadi di Nusantara, dan dari sini berusaha untuk menunjukkan respons keagamaan yang diberikan terhadap berbagai persoalan agraria yang dihadapi masyarakat tersebut, baik respons itu dalam bentuk "jaminan akses" maupun "kontra-eksklusi".

\section{Pergulatan Agraria di dalam Keluarga}

\section{Kasus 1: Bagian Waris Anak Perempuan}

Dalam hukum Islam, bagian waris anak perempuan adalah separuh dari bagian anak lelaki. Jadi, rasio antara anak laki-laki dan perempuan dalam

15 Keempat jenis persoalan agraria ini dijelaskan secara panjang lebar dalam: Mohamad Shohibuddin, Perspektif Agraria Kritis: Teori, Kebijakan dan Kajian Empiris, (Yogyakarta, Bogor dan Jakarta: STPN Press, Sajogyo Institute, PSA IPB, dan KPA, 2018), Bab 1. 
pembagian harta peninggalan orang tua adalah 2:1. Di sini kita melihat adanya alokasi akses yang tidak sama atas harta waris: anak perempuan mendapatkan proporsi bagian yang lebih kecil dibanding anak laki-laki. Ternyata, fakta ketidaksamaan hak waris di antara anak keturunan ini dapat menjadi sumber kegelisahan tersendiri ketika jenis harta warisan berupa tanah pertanian.

Dalam beberapa hadits dituturkan bahwa ketika Umar bin Khathab memperoleh harta rampasan perang berupa kebun kurma yang subur di Khaibar, ia justru merasa gundah gulana. Dalam pengakuan Umar, kebun ini merupakan harta benda paling berharga yang pernah dimilikinya. Kegalauan semacam ini dapat dijelaskan antara lain karena harta kaum Muhajirin ketika masih tinggal di Mekah pada dasarnya adalah harta yang berkaitan dengan aktivitas perniagaan, seperti modal, barang niaga, hewan tunggangan, dan harta-harta bergerak lainnya. Tetapi, setelah mereka hijrah ke Madinah dan kemudian sebagian dapat memiliki tanah pertanian, maka perkembangan ini memberi mereka suatu jenis property yang sama sekali baru. Sebab, tanah adalah jenis harta benda yang bersifat tidak bergerak (fixed property); jauh berbeda dari harta perniagaan yang bersifat "cair" dan menuntut perputarannya secara terus-menerus dalam usaha perdagangan.

Ketika Umar mengadukan kegalauannya kepada Rasulullah SAW, beliau memberikan solusi sebagai berikut: "Pertahankan pokok harta itu, lantas sedekahkanlah hasilnya!" Hadits inilah yang kemudian dijadikan ulama fiqh sebagai dalil bagi anjuran wakaf. Berdasarkan hadits ini, Umar memutuskan mewakafkan kebun kurmanya di Khaibar dan tidak menjadikannya sebagai harta peninggalan bagi ahli warisnya. Hasil panen dari kebun wakaf itulah yang kemudian dibagikan secara adil oleh Umar.

Menariknya, Umar menetapkan bahwa penerima manfaat (mawqûf 'alayh) dari kebun wakaf tersebut mencakup anggota keluarganya sendiri, dan baru kemudian masyarakat umum yang membutuhkan. Dengan kata lain, wakaf yang dilakukan Umar adalah kombinasi wakaf ahlî (sanak 
keluarga sebagai penerima manfaat) dan wakaf khayrî (masyarakat luas sebagai penerima manfaat). Sewaktu Umar menjabat khalifah, praktik wakaf ini kian digalakkan sementara sistem administrasinya juga terus diperbaiki. Sejak itu, wakaf semakin banyak dilakukan oleh umat Islam, termasuk dalam bentuk kombinasi wakaf ahlî dan wakaf khayrî.

Skema wakaf ahlî yang dipopulerkan Umar ini ternyata dapat menjadi solusi bagi kepedulian untuk menjamin akses anak perempuan yang setara atas harta peninggalan orang tua; sesuatu yang tidak bisa dilakukan apabila menggunakan aturan hukum waris semata. Dalam arti demikian, maka wakaf ahlî ini merupakan mekanisme "kontra-eksklusi" dan sekaligus "jaminan akses" bagi anak perempuan untuk memperoleh bagian yang lebih setara, tanpa harus menggugat ketentuan hukum waris.

Dalam kaitan ini, Islam Nusantara ternyata menunjukkan kepedulian tersendiri, yaitu dalam mengupayakan akses yang lebih setara atas harta waris di antara semua anak keturunan, sekaligus pada saat yang sama dapat tetap memenuhi ketentuan hukum waris itu sendiri. Di Jawa, apa yang dilakukan para kiai untuk keluar dari dilema ini adalah melalui hibah harta benda selama masih hidup, terutama yang ditujukan untuk harta tak bergerak seperti rumah dan tanah pertanian. Untuk harta lain yang tersisa, kebanyakan berupa harta bergerak, barulah dibagi sesuai ketentuan hukum waris. Dalam hibah harta yang tidak bergerak tadi sudah dipastikan bahwa anak perempuan juga memperoleh, sebagai misal, alokasi lahan sawah dengan luas yang kurang lebih sepadan dengan yang diterima anak lelaki.

Praktik semacam ini pernah diangkat secara khusus oleh Menteri Agama Munawir Sjadzali pada dekade 1990-an ketika melontarkan urgensi melakukan "Reaktualisasi Hukum Islam". Kendati gagasan ini kemudian memicu polemik luas, namun kepedulian Menteri Agama ini turut mendasari penyusunan naskah Kompilasi Hukum Islam (KHI). Naskah ini kemudian dituangkan menjadi Instruksi Presiden No. 1 Tahun 1991 sebagai pedoman bagi hakim dalam memutuskan perkara di pengadilan agama. 
Beberapa substansi KHI ini, karena itu, dapat dianggap sebagai artikulasi Islam Nusantara di bidang agraria yang di sini dalam bentuk kebijakan pemerintah.

\section{Kasus 2: Fragmentasi Lahan Pertanian Akibat Proses Pewarisan}

Isu lain terkait pergulatan agraria di tingkat keluarga yang juga penting diangkat adalah sistem hukum waris yang justru mendorong terjadinya fragmentasi atau pemecahan penguasaan lahan. Sebagaimana diketahui, hukum waris Islam menentukan bahwa seluruh harta peninggalan (di luar yang diwasiatkan) dibagi habis di antara para ahli waris dengan porsi yang telah ditetapkan secara rinci. Dengan demikian, semua ahli waris yang berhak akan memperoleh bagiannya masing-masing sesuai jatah yang telah ditentukan.

Ketentuan semacam ini pada dasarnya adalah ekspresi dari prinsip keadilan dalam hukum Islam. Jika harta waris tersebut adalah harta benda bergerak seperti dominan di Mekah pada masa hidup Nabi Muhammad SAW, maka pembagian-habis semacam ini tidak dirasakan sebagai suatu persoalan. Namun, bagaimana jika harta waris itu berupa lahan pertanian, seperti dominan di Madinah? Di sini lagi-lagi harus diingat perbedaan yang mendasar antara harta benda bergerak seperti harta perniagaan dengan harta benda yang tidak bergerak seperti lahan pertanian.

Dalam kasus terakhir, apabila harta peninggalan yang berupa lahan pertanian ini dibagi kepada seluruh ahli waris, maka luasannya akan terpecah-pecah alias terfragmentrasi. Apabila pola pewarisan semacam ini terus berlanjut pada generasi berikutnya, maka luas lahan akan semakin kecil dari waktu ke waktu. Akibatnya, usahatani yang dilakukan di atas lahan itu semakin lama menjadi kian tidak efisien lagi.

Jadi, di sini terdapat satu jenis tantangan eksklusi di mana prosesnya terjadi melalui fragmentasi lahan yang menyebabkan usaha pertanian terlampau kecil sehingga tidak memenuhi skala keekonomian. Kondisi 
inilah yang membuat para petani gurem kesulitan untuk bertahan. Mereka akhirnya terpaksa menjual lahan pertaniannya dan lantas beralih usaha ke sektor ekonomi lainnya. ${ }^{16}$ Atau, kalaupun ia masih sanggup bertahan melalui pengerahan berbagai strategi nafkah ganda, lahan gurem itu sudah tidak mungkin dipecah lagi ketika harus diwariskan kepada generasi berikutnya. Akhirnya, agar bisa diwariskan, lahan itu terpaksa dijual dan uang yang diperoleh dari hasil penjualan itu lantas dibagi kepada ahli waris sesuai aturan hukum Islam.

Lantas, adakah artikulasi Islam Nusantara dalam merespons tantangan ekslusi semacam ini? Secara normatif, sebenarnya UU No. 56/1960 tentang pembatasan luas lahan pertanian telah melarang keras pemindahan hak atas tanah pertanian jika hal itu akan menyebabkan pemilikan lahan pertanian kurang dari 2 ha (Pasal 9). Hanya saja, jika pemindahan hak ini terkait dengan pembagian harta waris, UU tersebut menyatakan bahwa akan ada ketentuan lebih lanjut yang mengaturnya berupa Peraturan Pemerintah (PP). Namun, sejauh yang penulis tahu, hingga kini PP turunan yang mengatur ihwal pewarisan ini belum pernah dikeluarkan.

Dalam kaitan ini, Pasal 189 KHI menyarankan agar lahan pertanian yang ukurannya sempit itu tidak dibagi-bagi sesuai ketentuan hukum waris, namun disarankan agar lahan itu dapat dikelola secara bersamasama. Hasil keuntungan dari pengolahan lahan itulah yang kemudian dibagi di antara para ahli waris yang berhak. Sayangnya, KHI tidak secara eksplisit menyebutkan apa solusi konkret yang harus dijalankan agar lahan peninggalan ini bisa dimiliki, dikelola dan dimanfaatkan secara bersamasama oleh para ahli warisnya. Namun, terlepas dari kekurangan ini, Pasal $189 \mathrm{KHI}$ tetap merupakan artikulasi Islam Nusantara yang penting dalam merespons ancaman khusus eksklusi ini, yaitu fragmentasi lahan yang terjadi akibat proses pewarisan.

16 Peralihan usaha ke non-pertanian ini kerap tidak menghasilkan "mobilitas vertikal", namun sekedar fenomena perpindahan kemiskinan dari desa ke sektor informal dan wilayah kumuh di kota. Lihat: Mohamad Shohibuddin, Ketimpangan Agraria di Indonesia: Pendekatan Studi, Kondisi Terkini dan Kebijakan Penanganan, (Bogor: IPB Press, 2020). 
Terkait dengan solusi semacam ini, di Minangkabau ada satu kategori harta benda yang disebut sebagai pusako tinggi. Jenis harta benda ini biasanya berupa lahan sawah atau kebun, demikian juga rumah gadang, yang berasal dari peninggalan leluhur dan tidak pernah diwariskan secara individual, akan tetapi dijadikan sebagai harta bersama milik semua anggota klan yang bersangkutan. Apabila "sumberdaya bersama" ini berupa lahan pertanian, maka ia bisa dimanfaatkan secara bergilir di antara para anggota klan yang membutuhkan dalam bentuk hak pakai. Sistem adat yang serupa juga bisa dijumpai di Muara Enim, Sumatera Selatan yang dikenal dengan istilah tunggu tubang. Dalam kedua sistem adat ini, anak perempuan yang tertua memiliki kedudukan kultural yang sangat penting, yaitu sebagai pihak yang akan menerima tanah pusako tinggi. Namun, hal ini bukan dalam arti transfer harta waris untuk dimiliki secara individual, melainkan lebih berkaitan dengan peran kultural anak perempuan tertua sebagai pengelola harta bersama milik keluarga besar.

Dengan demikian, pusako tinggi ini sebenarnya merupakan artikulasi yang genuine dari Islam Nusantara dengan signifikansi mampu menangkal ancaman eksklusi yang diakibatkan oleh kecenderungan fragmentasi lahan pertanian akibat proses pewarisan. Sebab, lahan pertanian yang termasuk kategori pusako tinggi ini tidak boleh diwariskan secara individual dari generasi ke generasi, akan tetapi dijadikan sebagai harta "milik bersama" di antara para ahli waris yang bahkan bisa mencakup beberapa generasi. ${ }^{17}$

Dalam pengertian demikian, maka pusako tinggi ini sebenarnya dapat dianalogikan dengan wakaf ahlî (yakni wakaf yang manfaatnya ditujukan untuk mereka yang termasuk sanak keluarga), hanya saja dalam konsepsi dan praktik kultural, bukan keagamaan. Pertanyaannya kemudian adalah: mengapa skema wakaf ahlî itu sendiri yang memang menyasar anggota keluarga tidak dikembangkan lebih lanjut sebagai cara untuk mencegah

17 Di luar jenis harta ini, dalam masyarakat Minangkabau dikenal kategori harta lain yang disebut sebagai harta pencaharian. Yang terakhir ini adalah harta hasil usaha orang tua sendiri yang dapat diwariskan kepada keturunannya secara individual. 
fragmentasi lahan pertanian akibat proses pewarisan? Sebagai contoh, jika seseorang memiliki lahan pertanian seluas 2 ha, maka ketimbang lahan itu dibagi habis di antara para ahli waris (dengan manfaat ekonomi yang jauh dari optimal), akan lebih baik jika lahan itu diwakafkan sehingga tidak bisa dialihkan atau dipecah-pecah penguasaannya. Meskipun lahan diwakafkan,

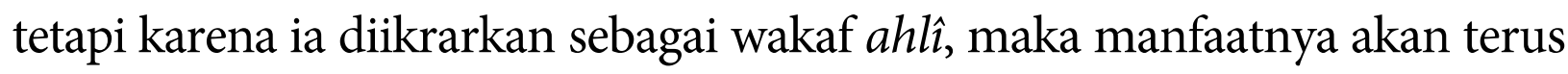
dapat dirasakan oleh semua ahli waris.

Selain itu, dalam ikrar wakaf ahlî ini juga dapat dinyatakan secara spesifik jenis penggunaan harta benda yang diwakafkan. Sebagai misal, apabila berupa tanah, maka pewakafannya dapat diikrarkan sebagai lahan pertanian dan tidak boleh dialihkan untuk fungsi lainnya, misalnya pertokoan atau perumahan. Dengan cara demikian, maka wakaf ahlî tidak hanya merupakan skema "kontra-fragmentasi" penguasaan lahan, namun pada saat yang sama juga skema "kontra-konversi" lahan pertanian.

Demikianlah, wakaf, berbeda dari zakat, menyediakan fleksibilitas yang tinggi kepada para pelaku wakaf (wâqif) untuk menetapkan, misalnya saja, apa tujuan peruntukan harta wakaf, siapa penerima manfaatnya, apa jenis manfaat yang disediakan, juga apa jenis penggunaan lahannya jika harta wakaf itu berupa tanah. Lebih lanjut, signifikansi wakaf semacam ini akan diuraikan di bawah nanti saat penulis membahas topik "wakaf agraria".

\section{Kasus 3: Hak Istri Ketika Terjadi Perceraian}

Kasus lain di tingkat keluarga yang juga penting diangkat dalam rangka menunjukkan respons Islam Nusantara terhadap pergulatan agraria adalah hak istri atas harta keluarga ketika terjadi perceraian. Menurut hukum Islam, ketika suami-istri bercerai, maka jaminan hak istri atas harta keluarga terbatas pada mahar yang telah diserahkan suaminya saat menikah, atau harta bawaan seperti harta warisan dari orang tua, atau harta pemberian yang pernah diterimanya. Dengan demikian, saat perceraian terjadi, maka harta yang dapat terus dimiliki oleh istri terbatas pada jenis-jenis harta benda ini dan pemberian dari suami saat ikrar talak dijatuhkan. Sementara 
harta lainnya yang diperoleh suami-istri selama masa pernikahan (marital property) sepenuhnya menjadi milik suami.

Ketentuan semacam ini mungkin dapat dimaklumi dalam konteks masyarakat Arab saat itu yang memang membatasi peran dan kontribusi perempuan pada ranah domestik semata. Namun, hal ini tentu saja sangat tidak cocok dengan kondisi sebagian besar masyarakat di wilayah Nusantara di mana peran dan kontribusi perempuan dalam perekonomian rumah tangga sangat penting dan signifikan. Di sinilah dapat ditemukan satu ekspresi yang sangat khas Islam Nusantara, yakni dikenalnya apa yang disebut sebagai "harta pencaharian bersama", yaitu harta yang dikumpulkan selama dalam ikatan perkawinan dengan hak yang sama terhadapnya di antara pasangan suami-istri.

Pengakuan atas konsep "harta pencaharian bersama" ini tentu tidak terlepas dari praktik-praktik berdasar hukum adat yang tersiar luas pada berbagai kelompok masyarakat Nusantara kendati dengan terminologi yang berbeda-beda: pohroh di Aceh, harta suarang di Minangkabau, hartou massou di Lampung, gono-gini di Jawa, cakkara di Makassar, barang partantangan di Banjar, dan sebagainya. Pengakuan ini bahkan selanjutnya dituangkan secara eksplisit dalam KHI, tepatnya pada Pasal 190. Berdasarkan pasal ini, terdapat "jaminan akses" dan sekaligus skema "kontra-eksklusi" bagi istri atas harta keluarga saat ia bercerai dari suaminya. Ketentuan ini memenuhi rasa keadilan masyarakat karena istri berperan besar dalam penciptaan harta keluarga saat berada dalam ikatan perkawinan.

\section{Pergulatan Agraria di Ranah Masyarakat}

\section{Kasus 1: Ketimpangan Hubungan Produksi ${ }^{18}$}

Tantangan akses dan ancaman eksklusi bukan semata-mata merupakan pergulatan menyangkut harta benda keluarga, akan tetapi juga pergulatan

18 Pembahasan pada bagian ini terutama didasarkan pada artikel Bilal Ibrahim, "Beyond State and Peasant: The Egalitarian Import of Juristic Revisions of Agrarian and Administrative Contracts in the Early Mamlūk Period." Islamic Law and Society 16, No 3-4 (2009). 
yang berlangsung dalam konteks relasi sosio-agraria yang lebih luas di ranah masyarakat. Salah satu bentuknya adalah pergulatan agraria yang terjadi akibat ketidakadilan hubungan produksi yang berlangsung di tengah-tengah masyarakat.

Apabila kita menengok sejarah Islam, salah satu fakta yang menarik adalah bahwa ketidakadilan dalam relasi produksi ini justru pernah diciptakan secara sistematis melalui kebijakan yang dikeluarkan negara, dalam hal ini adalah kekhilafahan Islam. Salah satu contohnya adalah kebijakan yang dilakukan Dinasti Mamluk ketika berusaha meningkatkan pendapatan pajak dan mengalokasikan tanah pertanian bagi personel militernya. Perlu diketahui, Dinasti Mamluk ini berasal dari para tentara bekas budak yang kemudian berhasil meraih kekuasaan politik dan lantas mendirikan dinasti sendiri dengan wilayah yang antara lain mencakup Mesir dan Syria. Seperti praktik yang lazim dilakukan para penguasa pada masa itu, Dinasti Mamluk juga banyak membagi-bagikan tanah pertanian atau mengalokasikan persentase tertentu dari pungutan pajak tanah (kharaj) kepada para tentara pendukungnya melalui skema kebijakan yang dikenal dengan istilah iqthâ. ${ }^{19}$ Praktik kebijakan iqthâ' semacam inilah yang melahirkan relasi-relasi feodalistik antara kelas militer dengan para petani penggarap. Dalam relasi semacam ini, pihak pertama menikmati surplus yang dihasilkan oleh pihak yang kedua, seringkali dengan proporsi yang sangat tidak adil melalui pembebanan biaya sewa tanah dan perjanjian bagi hasil yang sangat memberatkan..$^{20}$

Terkait hal ini, apa yang menarik dicermati adalah respons keagamaan yang disampaikan oleh golongan ulama fiqh dari mazhab Syafi'i dan mazhab Hanbali. Menyaksikan nestapa kaum petani, para ulama ini mengeluarkan

19 Dalam bentuk berbeda, alokasi tanah dan porsi tertentu dari hasil bumi semacam ini juga dijalankan oleh penguasa kerajaan Jawa, yakni apa yang dikenal dengan istilah lungguh.

20 Hal ini membuktikan bahwa sistem kekhilafahan Islam bersifat profan dan bahwa ketidakadilan juga dapat, dan telah, dilahirkan oleh sistem ini, sebagaimana juga telah dilahirkan oleh sistem politik dan pemerintahan lainnya. 
sejumlah fatwa seputar perjanjian sewa-menyewa tanah (ijârah) dan bagi hasil produk pertanian (muzâra'ah) dalam rangka melindungi hak dan kepentingan para petani penggarap. Hal ini menunjukkan tingginya kepekaan sosial para ulama saat itu dalam menyikapi persoalan agraria yang sedang digulati masyarakatnya, sekaligus menunjukkan kegigihan mereka menerjemahkan nilai-nilai humanis Islam ke dalam aturan fiqh yang memihak kepentingan petani. Berkat ijtihad ini, maka ketika petani menghadapi ancaman eksklusi dari kebijakan iqthâa yang diterapkan penguasa Dinasti Mamluk, maka mereka memiliki argumen keagamaan yang kuat untuk dapat menegosiasikan kepentingannya.

Ijtihad agraria sebagai respons terhadap relasi sosio-agraria yang tidak adil ternyata juga disuarakan oleh Nahdlatul Ulama (NU), seperti tampak pada beberapa keputusan Bahtsul Masail tingkat nasional yang diselenggarakan oleh organisasi ini. ${ }^{21} \mathrm{Hal}$ ini akan penulis bahas secara terpisah di bawah nanti.

\section{Kasus 2: Ancaman Pengambilalihan Tanah}

Ancaman eksklusi yang lebih kasat mata terjadi melalui proses pengambilalihan tanah dari petani (baca: enclosure). Pada umumnya, proses semacam ini terjadi sebagai konsekuensi dari ketidakadilan dalam politik alokasi tanah yang dijalankan oleh pemerintah. ${ }^{22}$

Di bawah sistem khilafah, bentuk eksklusi semacam ini juga pernah terjadi. Sebagai misal, Dinasti Mamluk dan Utsmaniyyah menjalankan kebijakan iqthâ' bukan untuk menyediakan lahan bagi rakyat, akan tetapi lebih untuk memfasilitasi kelompok elite dan kelas militer yang mendukung kekuasaannya. Ironisnya, kebijakan alokasi tanah dalam rangka konsolidasi

21 Hasil-hasil Bahtsul Masail NU tingkat nasional yang menyangkut isu agraria ini sudah pernah penulis tulis sebelumnya (Lihat: Mohamad Shohibuddin, Perspektif Agraria Kritis, Bab 9 dan 10). Dalam identifikasi penulis, paling tidak terdapat 53 keputusan Bahtsul Masail NU selama kurun waktu 1926-2017 yang membahas persoalan ketimpangan hubungan produksi ini.

22 Lihat: Mohamad Shohibuddin, Ketimpangan Agraria di Indonesia. Bab 7 buku ini menjelaskan praktik ketidakadilan politik alokasi ini, khususnya selama era reformasi. 
politikini sebagiannya juga dilakukan dengan cara menggusur para petani dari tanah-tanah pertanian yang mereka garap.

Kisah perampasan tanah petani di bawah kedua dinasti ini dijelaskan dengan baik sekali oleh Johansen, seperti tercermin pada anak judul bukunya yang sangat terus terang itu. ${ }^{23}$ Lebih jauh, Abbasi bahkan menyatakan bahwa pengambilalihan tanah dari para petani ini tidak hanya terjadi di bawah kedua dinasti di atas, tetapi juga di bawah dinasti Islam lainnya. Memang, hal ini merupakan praktik yang banyak dijalankan para penguasa pada masa itu di belahan dunia mana pun, sampai-sampai sejarawan akan menyebut secara khusus penguasa yang tidak melakukan hal tersebut. ${ }^{24}$

Padahal, ancaman pengambilalihan tanah inilah yang oleh Khalifah Umar justru berusaha dihindari, misalnya ketika beliau memutuskan untuk tidak membagi-bagi tanah pertanian di Irak kepada tentara Islam yang menaklukkannya. Beberapa sahabat senior (antara lain Bilal bin Rabah) menentang keras keputusan ini dan menuding Umar melanggar hukum Islam mengenai pembagian harta rampasan perang (ghanîmah). Namun, Umar tetap bersikukuh pada keputusannya ini karena ia lebih concern pada pencegahan akumulasi harta di antara tentara Islam dan ancaman kehilangan tanah garapan di antara penduduk lokal. Sebab, jika yang terakhir ini terjadi, maka selain bertentangan dengan prinsip keadilan, hal itu juga akan menghambat proses penerimaan Islam di antara penduduk lokal. ${ }^{25}$

23 Lihat: Baber Johansen, The Islamic Law on Land Tax and Rent: Peasants' Loss of Property Rights as Interpreted in the Hanafite Legal Literature of the Mamluk and Ottoman Periods, (London, New York, Sydney: Croom Helm, 1988).

24 Lihat: Muhammad Zubair Abbasi, “The Classical Islamic Law of Waqf: A Concise Introduction.” Arab Law Quarterly 26, No. 2 (2012): p. 123. Dengan demikian, jika ada yang menganggap iqthâ' sebagai konsep hukum Islam yang sepenuhnya ideal, bahkan dijadikan padanan "land reform" dalam pengertian modern, maka apa yang sebenarnya terjadi adalah bahwa konsep ini bersifat dinamis. Ketika dijalankan oleh Rasulullah dan para pemimpin penerusnya yang adil, iqthâ merupakan mekanisme penyediaan akses tanah pertanian kepada masyarakat secara luas. Namun dalam perkembangannya, iqthẩ ini juga dapat (dan telah) disalahgunakan oleh para penguasa untuk menguntungkan diri sendiri dan memapankan kekuasaannya.

25 Untuk menguatkan keputusannya ini, Khalifah Umar mengutip QS. Al-Hasyr/59: 7 yang salah satu bagiannya menegaskan demikian: “... agar harta itu jangan hanya beredar di antara orang-orang kaya saja di antara kamu." 
Di Indonesia, eksklusi dalam bentuk pengambilalihan tanah rakyat ini banyak terjadi, terutama akibat kebijakan pemerintah memberikan konsesi tanah luas untuk perkebunan, kehutanan, pertambangan, industri, pariwisata, dan sebagainya. Namun, ada satu kasus yang secara khusus perlu diangkat dalam kaitan dengan artikulasi Islam Nusantara ini, yaitu lenyapnya tanah-tanah perdikan pesantren yang dahulu pernah eksis di daerah-daerah seperti Giri, Urutsewu, Mlangi, Krapyak, dan sebagainya. Padahal, tanah-tanah perdikan itu pernah berfungsi sebagai jaminan akses tanah dan landasan kemandirian ekonomi di antara komunitas pesantren.

Semangat nasionalisme yang berlebihan di awal periode kemerdekaan dan gejolak pemberontakan daerah yang marak terjadi di era 1950-an telah melahirkan bias unifikasi hukum yang sering kali tidak ramah pada ekspresi dan tuntutan lokal, termasuk yang terkait sistem tenurial. Hal inilah yang turut menyebabkan tanah perdikan pesantren meluruh dan akhirnya lenyap menjadi hak milik perorangan. Karena dianggap sebagai warisan "feodalisme", tanah-tanah perdikan pesantren itu kemudian diserahkan kepada para petani penggarapnya dalam bentuk hak milik penuh, sesuai dengan ketentuan konversi dalam UU Pokok Agraria.

Padahal, tidak semua tanah perdikan dapat digeneralisir sebagai bersifat feodal. Sebaliknya, mengacu pada tuturan lisan (meskipun hal ini harus dilengkapi data pendukungnya, misalnya dalam bentuk manuskrip pesantren), beberapa pesantren adalah penyelenggara pemerintahan perdikan yang menjalankan fungsi publik di wilayahnya, termasuk mengatur redistribusi manfaat dari tanah-tanah perdikan di antara semua warganya (antara lain dalam bentuk hak pakai secara bergilir). ${ }^{26}$ Namun, kuatnya bias unifikasi dalam hukum agraria nasional telah membuat kebijakan konversi hak milik juga diberlakukan pada kategori tanah perdikan ini.

26 Tuturan lisan semacam ini penulis peroleh antara lain dari Kiai Seniman, salah satu tokoh yang memimpin masyarakat Urut Sewu mempertahankan tanah garapannya dari klaim pihak militer. Dalam arti demikian, maka tanah perdikan pesantren memiliki karakter yang sangat berbeda dari desa-desa perdikan di Banyumas yang memang bersifat feodal dan dipimpin oleh penguasa perdikan secara turun temurun. Desadesa feodal di Banyumas inilah yang kemudian dibubarkan oleh pemerintah berdasarkan UU No. 13/1946, lalu tanahnya dibagikan sebagai hak milik individual kepada para petani penggarapnya. 
Akibatnya, semua tanah perdikan pesantren dijadikan hak milik individual tanpa menyisakan kewenangan publik apa pun bagi pesantren untuk mengaturnya. ${ }^{27}$

Lantas, apa respon masyarakat terhadap ancaman eksklusi dalam bentuk pengambilalihan tanah semacam ini? Dalam kasus petani yang kehilangan tanah di bawah Dinasti Mamluk dan Utsmaniyyah, Abbasi menemukan bahwa respons yang mereka lakukan adalah dengan mewakafkan tanahtanah mereka sebagai antisipasi agar tidak disasar oleh kebijakan iqthâ'. Menurut hukum Islam, harta benda yang telah diwakafkan merupakan "harta milik Allah" dan tidak dapat diambil oleh siapa pun dengan dalih apa pun. Pemanfaatan skema wakaf semacam ini ternyata sangat efektif bagi perjuangan kontra-eksklusi karena ia mampu menghalangi para penguasa dinasti Islam, bahkan yang paling tiran sekali pun, untuk memaksakan kemauannya ke kategori tanah wakaf. Hal ini merupakan salah satu faktor yang menjelaskan mengapa tanah wakaf banyak sekali dijumpai di Mesir, Syria, Turki, Tunis dan Aljazair. Bahkan hingga awal abad XX, antara setengah hingga sepertiga tanah pertanian di wilayah kekuasaan Dinasti Utsmaniyyah termasuk kategori tanah wakaf ini. ${ }^{28}$

Signifikansi wakaf sebagai skema kontra-eksklusi ini bahkan terus berlanjut hingga jauh hari kemudian ketika kolonialisme mulai menguasai sebagian besar dunia Muslim. Sebagai contoh, ketika Prancis menjajah Aljazair, dan para pemukim Prancis mulai berusaha memperoleh tanah untuk melayani berbagai jenis aktivitas ekonomi, mereka kesulitan mendapatkan tanah yang cukup luas dari penduduk lokal. Hal ini karena sebagian besar tanah di Aljazair telah dijadikan sebagai tanah wakaf sejak jauh hari sebelumnya. Kondisi inilah yang lantas mendorong pemerintah kolonial untuk menjalankan strategi deligitimasi atas institusi wakaf dalam

27 Hal yang sama juga terjadi pada masyarakat hukum adat yang sebagiannya di masa lampau pernah menyelenggarakan fungsi publik di wilayah ulayatnya. Lihat: Mohamad Shohibuddin, Ahmad Nashih Luthfi, Westi Utami, ed. Meninjau Ulang Pengaturan Hak Adat, (Yogyakarta dan Bogor: STPN Press dan Pusat Studi Agraria IPB, 2019).

28 Muhammad Zubair Abbasi, “The Classical Islamic Law of Waqf,” p. 122-123. 
rangka merintis jalan bagi mereka untuk dapat memperoleh tanah luas. Powers dalam salah satu tulisannya menguraikan kebijakan deligitimasi oleh pemerintah kolonial Prancis ini secara rinci, sebagaimana yang terangkum dalam kutipan singkat di bawah ini:

“... pendudukan Aljazair [oleh Prancis] menimbulkan konflik yang tidak terelakkan antara hukum Islam dan para colons (pemukim asal Prancis). Upaya-upaya oleh pihak terakhir ini untuk mendapatkan tanah sering digagalkan oleh kenyataan bahwa banyak tanah di Aljazair telah diikrarkan sebagai tanah wakaf, dan karenanya, menurut hukum, tidak dapat diperjual-belikan di pasar terbuka. Pemerintah kolonial berupaya keras dapat mengendalikan institusi wakaf ini dengan cara mengeluarkan berbagai aturan perundang-undangan. Upaya yang dilakukan pemerintah ini memperoleh dukungan dari para ilmuwan orientalis Prancis dengan berkampanye mendiskreditkan institusi wakaf di antara warga Aljazair sendiri. Kampanye semacam ini, yang tercermin dalam berbagai kajian mengenai wakaf yang mereka tulis antara 1875-1905, telah menimbulkan dampak yang nyata pada kajian di masa-masa berikutnya mengenai institusi wakaf." 29

Di wilayah Nusantara, wakaf sebagai skema kontra-eksklusi atas kebijakan pengambilalihan tanah oleh pemerintah kolonial ini memang tidak ditemukan. Hal ini dapat dimaklumi karena wakaf, sebagai skema donasi keagamaan, pada waktu itu belum menjadi praktik yang populer di antara penduduk Nusantara. Namun, pernyataan yang terakhir ini berlaku hanya ketika konsep wakaf dipahami sebatas sebagai pranata hukum Islam semata. Akan tetapi, apabila perjuangan kontra-eksklusi semacam ini dimaknai secara lebih longgar hingga mencakup konsep kultural pusako tinggi seperti yang telah diuraikan di atas, maka sebenarnya inisiatif yang serupa dengan skema wakaf juga telah banyak dilakukan masyarakat di berbagai wilayah Nusantara, terutama yang didasarkan pada pranata hukum adat.

29 David Powers, "Orientalism, Colonialism, and Legal History: The Attack on Muslim Family Endowments in Algeria and India." Comparative Studies in Society and History 31, No. 3 (1989): p. 535-536. 


\section{Ijtihad Agraria Nahdlatul Ulama}

\section{Ijtihad Kolektif Level Nasional}

Secara kelembagaan, NU telah banyak mengeluarkan ijtihad kolektif di bidang agraria. Ijtihad kolektif yang penulis maksud di sini adalah keputusan NU secara organisatoris yang diambil dalam forum-forum resmi pengambilan keputusan pada tingkat nasional, yaitu Muktamar, Konferensi Besar dan Musyawarah Nasional Alim Ulama NU. Apabila dicermati hasilhasil forum nasional NU ini, mulai Muktamar pertama tahun 1926 hingga Musyawarah Nasional Alim Ulama tahun 2017, paling tidak terdapat 69 ijtihad kolektif NU yang terkait, dan bahkan secara khusus membahas, isuisu yang secara tipikal mencerminkan empat kategori "persoalan agraria" yang telah disebutkan di awal artikel ini. Karena itulah, maka ijtihad kolektif yang dikeluarkan NU itu dapat dikualifikasikan sebagai "ijtihad agraria”.

Apabila dipetakan secara rinci, dari 69 ijtihad kolektif NU itu sebanyak 30 keputusan terkait/membahas persoalan agraria yang pertama, lantas 25 keputusan terkait/membahas persoalan kedua. Selanjutnya, persoalan agraria ketiga disinggung/dibahas dalam 53 keputusan. Terakhir, persoalan agraria yang keempat disinggung/dibahas dalam 7 keputusan. Jika kesemua keputusan Bahtsul Masail ini dijumlah menurut empat kategori persoalan agraria, maka secara keseluruhan ijtihad kolektif NU di bidang agraria ini mencapai 115 buah. Hal ini karena ada beberapa keputusan yang isinya menyinggung/membahas lebih dari satu kategori persoalan agraria.

Selanjutnya, apabila dipetakan menurut periodenya, dari 115 ijtihad kolektif NU ini, era reformasi mencatatkan jumlah ijtihad agraria terbanyak (56 buah), disusul era kolonial Belanda (39 buah), era Orde Baru (13 buah), dan paling sedikit era Demokrasi Terpimpin ( 7 buah). Pada era pendudukan Jepang hingga era Revolusi Kemerdekaan (1942-1949), jumlah ijtihad kolektif yang dikeluarkan NU tidak diketahui pasti karena dokumentasi hasil-hasil Muktamar, Konbes dan Munas Alim Ulama yang berlangsung pada dua periode ini belum berhasil diketemukan hingga sekarang. 


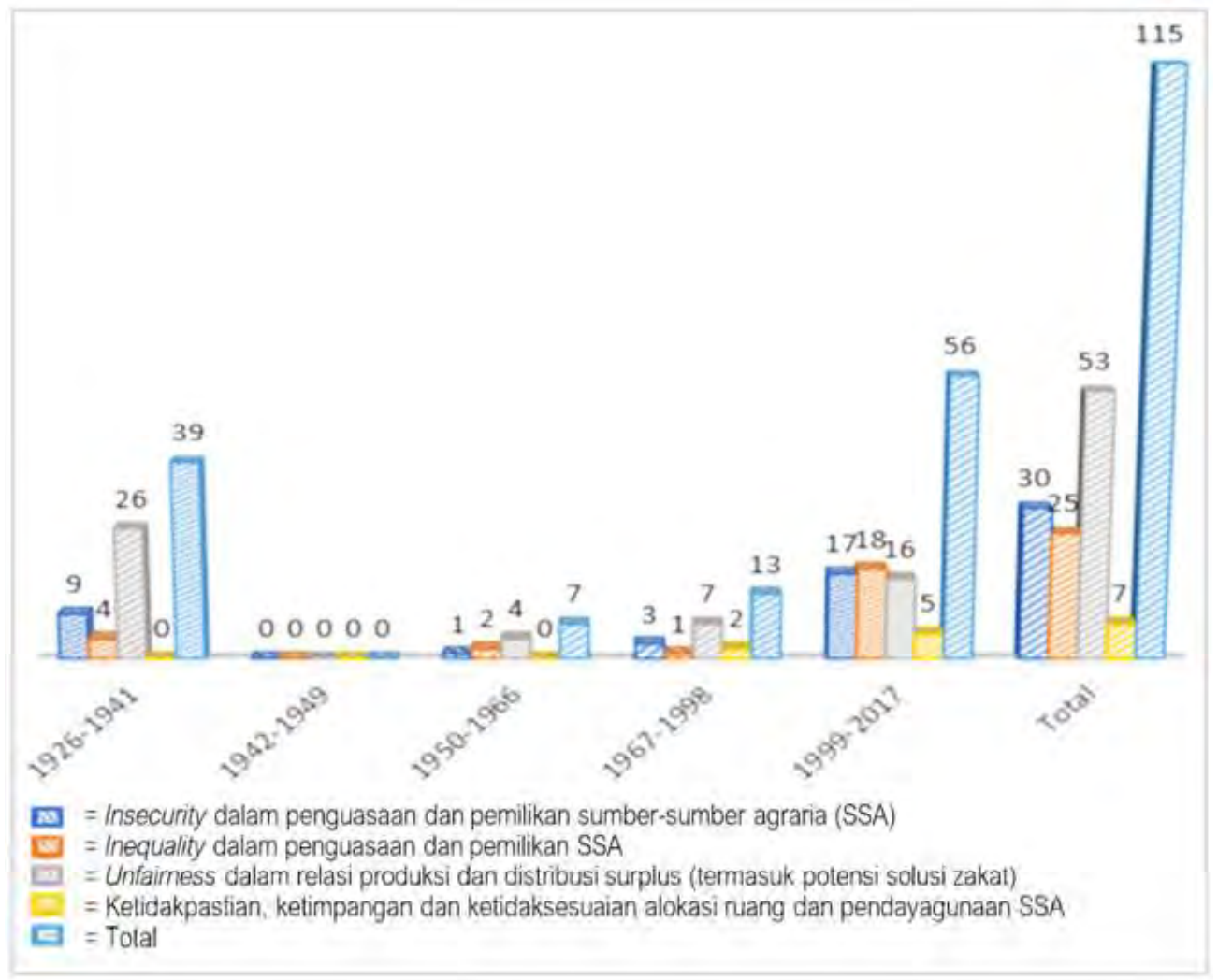

\section{Gambar 2. Pemetaan Ijtihad Agraria NU Berdasarkan Kategori Persoalan Agraria yang Dibahas, 1926-2017 ${ }^{30}$}

Lantas, bagaimanakah ijtihad agraria NU menyikapi empat persoalan agraria di atas? Seperti halnya berbagai ekspresi Islam Nusantara yang dipaparkan terdahulu, di sini ijtihad agraria NU juga bergulat dengan dua jenis perjuangan, yakni "mewujudkan akses" dan "menangkal eksklusi". Kedua hal ini diartikulasikan NU baik dalam konteks respons terhadap ketidakpastian dan ketimpangan tenurial (persoalan agraria pertama dan kedua) maupun terhadap ketidakadilan relasi produksi dan perburuhan (persoalan agraria ketiga). Namun, ada satu kategori persoalan agraria lain yang ternyata disuarakan dalam ijtihad agraria NU dan tidak dijumpai pada artikulasi Islam Nusantara yang diulas sebelumnya, yaitu perjuangan akses dan kontra-eksklusi dalam rangka kepedulian lingkungan hidup dan gerakan ekologi yang merupakan respons atas persoalan agraria keempat. ${ }^{31}$

30 Dikutip dari Mohamad Shohibuddin, Perspektif Agraria Kritis, p. 157.

31 Keterbatasan ruang tidak memungkinkan penulis untuk mendiskusikan secara terinci "ijtihad agraria" NU menyangkut keempat persoalan agraria ini. Bagi yang berminat untuk mendalaminya, silahkan lihat: Mohamad Shohibuddin, Perspektif Agraria Kritis, Bagian V. 


\section{NU dan Kontroversi Land Reform}

Masih berkaitan dengan ijtihad agraria NU, secara khusus pada bagian ini penulis juga ingin menjernihkan satu isu yang cukup kontroversial, yaitu mengenai pandangan dan posisi NU terhadap agenda land reform. Isu ini sangat penting dijernihkan karena stigma "anti-land reform" sudah lama dilekatkan kepada NU_dan bukannya tanpa alasan yang kuat_antara lain karena tiga faktor sebagai berikut.

Pertama, NU secara kelembagaan pernah mengeluarkan keputusan yang menyatakan bahwa land reform adalah haram kecuali dalam keadaan darurat. Keputusan ini ditetapkan dalam Konferensi Besar Syuriyah NU di Jakarta pada 11-13 Oktober 1961. Sayangnya, apa yang dimaksudkan dengan "keadaan darurat" ini tidak dijelaskan sama sekali. Akibatnya, berkembang kesan kuat bahwa kebijakan land reform secara kategoris ditolak sama sekali oleh NU.

Kedua, pelaksanaan land reform selama paruh awal dekade 1960-an memang penuh dengan benturan sosial. Hal ini terjadi ketika Barisan Tani Indonesia (BTI) mengorganisir berbagai "aksi sepihak" untuk mendesakkan pelaksanaan perjanjian bagi hasil (UU No. 2/1960) dan land reform (UU No. 56/1960). "Aksi-aksi sepihak" BTI ini mendapatkan penentangan keras dari para tuan tanah dan sebagian rakyat pedesaan, khususnya di Jawa, yang kebanyakan memang berafiliasi pada partai NU.

Ketiga, selama periode ini juga terjadi banyak kasus di mana argumen wakaf disuarakan oleh para tokoh agama dalam rangka mencegah tanahtanah di lingkungan pesantren yang melebihi batas maksimum dijadikan sebagai sasaran pelaksanaan land reform. Sebagian tokoh agama ini adalah kalangan elite lokal NU yang mempunyai pengaruh kuat di daerahnya. ${ }^{32}$

Mengenai kontroversi pertama, keputusan pengharaman land reform

32 Dua isu pertama sudah pernah dijernihkan penulis (lihat: Mohamad Shohibuddin, Perspektif Agraria Kritis, Bab 10). Namun, klarifikasi isu yang ketiga baru disampaikan di sini. 
memang merupakan sesuatu yang "melawan arus". Sebab, sepanjang satu tahun sebelumnya telah terbit sejumlah regulasi yang menjadi landasan pelaksanaan kebijakan reforma agraria, yaitu: UU Perjanjian Bagi Hasil (No. 2/1960), UU Pokok Agraria (No. 5/1960), UU Pembatasan Luas Lahan Pertanian (No. 56/1960; dikenal dengan UU Land Reform), dan beberapa aturan turunan yang terkait. Anehnya, argumen yang dinyatakan dalam keputusan Bahtsul Masail NU tahun 1961 sama sekali tidak merujuk beberapa regulasi ini, namun justru lebih merespons perdebatan ideologis era Perang Dingin antara kapitalisme dan sosialisme serta posisi Islam di dalamnya. Hal ini terlihat jelas dari rujukan yang dimuat dalam keputusan tersebut yang tidak mengutip kitab-kitab fiqh empat Mazhab seperti biasa dilakukan, akan tetapi sepenuhnya merujuk karya-karya kontemporer dari beberapa pemikir Muslim Timur Tengah yang terlibat dalam perdebatan ideologis itu. Secara lebih khusus, pandangan para pemikir Timur Tengah yang dirujuk dalam forum Konbes NU ini adalah seputar sakralitas hak milik yang sangat dijunjung tinggi dalam Islam.

Penggunaan argumen sakralitas hak milik sebagai dasar mengharamkan land reform, tentu saja, adalah "salah alamat". Sebab, UU Pokok Agraria (UUPA) secara eksplisit mengakui eksistensi hak milik individu. Hanya saja, UUPA menegaskan bahwa semua hak atas tanah mempunyai fungsi sosial (sebuah prinsip yang juga sangat ditekankan hukum Islam). Karena itu, UUPA menghendaki penghapusan hubungan eksploitasi di lapangan agraria, baik hal itu terwujud dalam penguasaan tanah maupun dalam berbagai relasi penyakapan yang berlangsung di atasnya (sewa menyewa, bagi hasil, gadai dan sebagainya). Dalam melakukan koreksi atas hubungan eksploitasi ini, tidak berarti bahwa pemerintah berhak untuk mengambil alih secara semena-mena tanah objek land reform dari tangan pemiliknya. Alih-alih, upaya pembaruan itu harus dilakukan sesuai prosedur resmi yang ditetapkan dan disertai ganti rugi yang layak.

Terlepas dari keputusan kontroversial ini, namun penting dicatat bahwa pandangan yang negatif terhadap land reform ini bukanlah suara tunggal 
di tubuh NU sendiri. Dalam kaitan ini, perlu ditekankan bahwa justru dua figur intelektual NU, yaitu Soewahjo Soemodilogo dan Prof. Soenario, merupakan tokoh-tokoh kunci dalam "Panitia Agraria"; sebuah kelompok kerja yang ditugaskan merumuskan draft UUPA sebelum dibahas dan disahkan di parlemen. ${ }^{33}$ Sementara tokoh-tokoh NU lainnya yang duduk di parlemen, Dewan Pertimbangan Agung maupun di kabinet pemerintah memiliki pandangan yang sama dalam mendukung legislasi reforma agraria (UUPA, UUPBH, UU Land Reform) serta pelaksanaannya oleh pemerintah.

Terkait kontroversi kedua, anggapan bahwa dalam praktik di lapangan banyak kiai dan warga NU melakukan tindakan yang berlawanan dari kebijakan pimpinan nasionalnya dengan menentang program land reform merupakan suatu anggapan yang tidak mewakili kenyataan seutuhnya. Memang, gontok-gontokan yang melibatkan massa BTI dan NU terjadi di banyak daerah yang tidak jarang memakan korban jiwa. Namun, patut dicatat bahwa ada konteks sosial-politik lebih luas yang harus juga disadari untuk dapat memahami gejolak penuh kekerasan ini, yaitu persaingan politik dan ideologi yang sengit di pusat pemerintahan yang melibatkan Presiden Soekarno sendiri, militer, serta faksi-faksi politik yang dipaksa menyatu ke dalam front NASAKOM (nasionalis, agama dan komunis).

Dalam situasi demikian, agenda land reform akhirnya tersedot ke dalam pusaran pertarungan politik di tingkat pusat, dan bahkan menjadi "ajang pertarungan" itu sendiri, ketika berbagai kekuatan nasional tersebut berebut dominasi politik di pedesaan dengan memobilisasi "politik aliran" di antara petani dan warga pedesaan. Negara, yang saat itu kondisinya masih lemah, justru tersandera dalam arus politisasi agenda land reform ini, alih-alih mampu mengorganisasikan pelaksanaannya secara baik, tertib dan sistematis. Akibatnya, di tingkat grass root, pelaksanaan land reform justru

33 Kedua tokoh ini bahkan berturut-turut merupakan Ketua dari Panitia Agraria ketiga dan keempat. Hal ini sesuai penjelasan Gunawan Wiradi, seorang tokoh peneliti dan pejuang senior reforma agraria. Lihat: Gunawan Wiradi, "Mencoba Memperkenalkan Pendekatan Baru," prolog untuk buku Mohamad Shohibuddin, Perspektif Agraria Kritis, p. xlix-lv. 
diwarnai oleh "spiral aksi dan reaksi" yang kian memanas di antara berbagai pendukung faksi-faksi politik nasional yang saling bertentangan.

Dengan demikian, bentrokan fisik antara massa NU dan BTI harus dipahami sebagai konsekuensi yang tak terelakkan dari kontestasi kekuatan nasional melalui mobilisasi "politik aliran" semacam ini. Tegasnya, hal itu tidak bisa dipahami sepenuhnya sebagai konfrontasi dua posisi diametral terhadap program land reform. Bahwa di lapangan massa NU tidak dapat sepenuhnya dicap sebagai penentang land reform akan tampak jelas apabila dicermati kiprah organisasi tani NU sendiri, yakni PERTANU. Seperti diulas Luthfi, PERTANU justru sangat gigih di lapangan dalam memperjuangkan pelaksanaan program land reform. Bahkan perjuangan ini terus dijalankan secara konsisten oleh organisasi ini di tengah kuatnya arus balik kontraland reform pasca tragedi "peristiwa 1965", sebagaimana diperlihatkan oleh PERTANU Cabang Banyuwangi. ${ }^{34}$

Satu lagi isu kontroversial yang penting dijernihkan adalah seputar penggunaan argumen wakaf untuk menghalangi land reform. Bahwa wakaf pada era 1960-an pernah digunakan oleh sebagian pihak untuk menghindarkan tanah-tanah tertentu dari sasaran land reform merupakan fakta sejarah yang tidak dapat dipungkiri. Namun, kenyataan tersebut selama ini dijelaskan dengan narasi tunggal semata, yaitu sebagai bentuk counter-reform dari para tuan tanah dengan menyalahgunakan dalil agama.

Meski penjelasan ini tepat untuk beberapa kasus, namun penjelasan yang lebih bernuansa perlu dipertimbangkan. Sebagai misal, kendati hal ini masih bersifat hipotetis, sebenarnya amat masuk akal untuk membayangkan dua penjelasan berikut ini sebagai narasi alternatif. Pertama, bahwa tanah yang hendak dijadikan sasaran land reform itu sejak semula memang benar-benar tanah wakaf yang ikrarnya bersifat informal dan tidak pernah

34 Ahmad Nashih Luthfi, "Sejarah dan Revitalisasi Perjuangan Pertanian Nahdlatul Ulama Melawan Ketidakadilan Agraria." Bhumi: Jurnal Agraria dan Pertanahan 3, No. 2 (2017). Artikel Luthfi ini didasarkan pada arsip-arsip militer yang dibuang oleh satu lembaga penelitian pada perguruan tinggi negeri dan kemudian ditemukannya secara tidak sengaja. 
dicatatkan dalam administrasi pemerintah (sesuatu yang amat lazim pada masa itu, dan bahkan masih terus berlangsung hingga saat ini). Sayangnya, prosedur untuk memastikan status sebenarnya dari klaim tanah wakaf tidak selalu dapat dilakukan di tengah panasnya persaingan politik pada masa itu. Salah satu penyebabnya adalah keanggotaan panitia land reform sendiri yang sering kali terlanjur bias dan sangat terpolitisasi. Padahal, pimpinan pusat NU sendiri secara terbuka sudah meminta agar klaim-klaim tanah wakaf diusut secara tuntas. ${ }^{35}$ Apabila klaim-klaim itu terbukti palsu, maka para pimpinan NU secara tegas menyatakan bahwa perbuatan itu merupakan aksi kriminal yang harus ditindak secara tegas oleh pemerintah. Sebaliknya, jika klaim-klaim itu terbukti benar, maka tanah wakaf tersebut harus dikeluarkan dari sasaran pelaksanaan program land reform.

Kedua adalah kemungkinan bahwa tanah yang hendak dijadikan objek land reform itu termasuk tanah-tanah di wilayah pesantren kuno yang dulunya merupakan wilayah perdikan. Tanah-tanah perdikan ini memang bukan tanah wakaf, namun berada di bawah pengaturan dan pengelolaan pesantren yang menjalankan kewenangan publik di atasnya. Karena itu, jika hipotesis ini tepat, maka upaya untuk menjadikan tanah-tanah ini sebagai sasaran program land reform akan ditanggapi oleh pihak pesantren sebagai suatu serangan atas kewenangan dan otonomi pesantren di wilayah perdikannya sendiri. Sebagai respons pembelaan diri, dalih wakaf lantas dijadikan sebagai argumen keagamaan oleh kalangan ini untuk menentang program land reform tersebut. Meskipun argumen semacam ini secara hukum tidaklah tepat, namun sebenarnya ia didasarkan pada kenyataan sosiologis yang pekat. ${ }^{36}$

35 KH. Idham Chalid, Ketua Umum PBNU saat itu, menegaskan: “... jikalau tanah wakaf itu adalah hibah wakaf palsu atau imitasi, kami dari kalangan agama dan Alim Ulama akan mengutuk perbuatan ini sebagai suatu perbuatan yang paling terkutuk, karena menjual nama Tuhan untuk kepentingan perutnya sendiri. Marilah kita selidiki secara jujur dan sungguh-sungguh betulkah itu suatu hibah yang jujur, suatu wakaf, ataukah itu suatu tempat berlindung tuan-tuan tanah untuk menjadi camouflage guna melindungi hak miliknya." Lihat: Mohamad Shohibuddin, Perspektif Agraria Kritis, p. 143.

36 Tentu saja, kemungkinan penjelasan yang terakhir ini perlu diteliti lebih lanjut. Bagaimanapun, hal ini menegaskan bahwa penjelasan tunggal seputar kontroversi wakaf dan land reform perlu ditinjau kembali, termasuk dengan bersandar pada sejarah lisan. 
Terlepas dari upaya klarifikasi historis di atas, namun yang lebih penting dalam konteks kekinian adalah perkembangan baru dalam ijtihad kolektif NU mengenai hukum land reform. Pada 2017, dalam forum Munas Alim Ulama di Mataram, Nusa Tenggara Barat, NU secara resmi mengeluarkan fatwa mengenai kewajiban pemerintah menjalankan program redistribusi lahan. Keputusan Munas ini dapat dianggap sebagai "koreksi resmi" NU secara kelembagaan atas apa yang diputuskan pada 56 tahun sebelumnya, yakni dari penetapan keharaman menjadi kewajiban hukum land reform. ${ }^{37}$

\section{Usulan Wakaf Agraria}

Di luar kontroversi seputar kaitan wakaf dan land reform ini, pada beberapa uraian di depan penulis telah menunjukkan kasus-kasus di mana wakaf merupakan skema yang efektif dalam upaya-upaya "menjamin akses" dan sekaligus "menghindarkan eksklusi". Signifikansi wakaf semacam inilah yang telah penulis kembangkan menjadi konsep "wakaf agraria" ${ }^{38}$ Konsep ini penulis definisikan sebagai: tindakan inisiator atau pelaku wakaf untuk menggalang dan/atau mewujudkan harta benda wakaf yang terutama berupa (namun tidak terbatas pada) tanah dengan ditentukan secara spesifik aspek-aspek tata kuasa, tata guna dan tata produksinya untuk dikelola dan dikembangkan menjadi usaha pertanian (dalam arti luas) dan/atau fungsi lindung dalam rangka mewujudkan sumber kesejahteraan rakyat dan sekaligus menjamin keberlanjutan ekologis.

Secara ringkas, formulasi konsep wakaf agraria ini bertolak dari dua kenyataan berikut. Pertama, wakaf merupakan filantropi sosial yang dapat mewujudkan res extra-commercium, yakni harta benda yang berada di luar "lalu lintas perdagangan"; atau dengan kata lain, menjadikannya bukan lagi komoditas karena sudah dikembalikan sebagai "harta benda milik Tuhan". Kedua, wakaf merupakan filantropi sosial yang memberikan pelakunya

37 Lihat Lampiran 1 untuk perbandingan antara dua keputusan NU mengenai hukum land reform ini.

38 Lihat Mohamad Shohibuddin, Wakaf Agraria: Signifikansi Wakaf Bagi Agenda Reforma Agraria, (Yogyakarta dan Bogor: Baitul Hikmah, Magnum Pustaka Utama dan Sajogyo Institute, 2019). Lihat juga: Mohamad Shohibuddin, "Mempertimbangkan Wakaf Sebagai Skema Alternatif Pelaksanaan Tenure Reform" dalam Mohamad Shohibuddin dan Adi D. Bahri, ed. Perjuangan Keadilan Agraria, p. 315-334. 
(wâqif) fleksibilitas besar untuk menentukan batasan-batasan mengenai peruntukan harta wakaf, bentuk penggunaannya, jenis manfaatnya, para penerima manfaatnya, dan pengelolanya. Kesemua ketentuan ini, begitu dinyatakan wâqif dalam ikrar wakafnya, maka ia bersifat konstitutif dan memiliki kedudukan legal yang kuat. Seperti dinyatakan satu kaidah fiqh: syurûth al-wâqif ka nash al-syarî yang berarti "ketentuan-ketentuan yang ditetapkan oleh pelaku wakaf (atas harta yang diwakafkannya) bersifat sama mengikatnya seperti teks syarî̀ (al-Qur'an dan hadits)”.

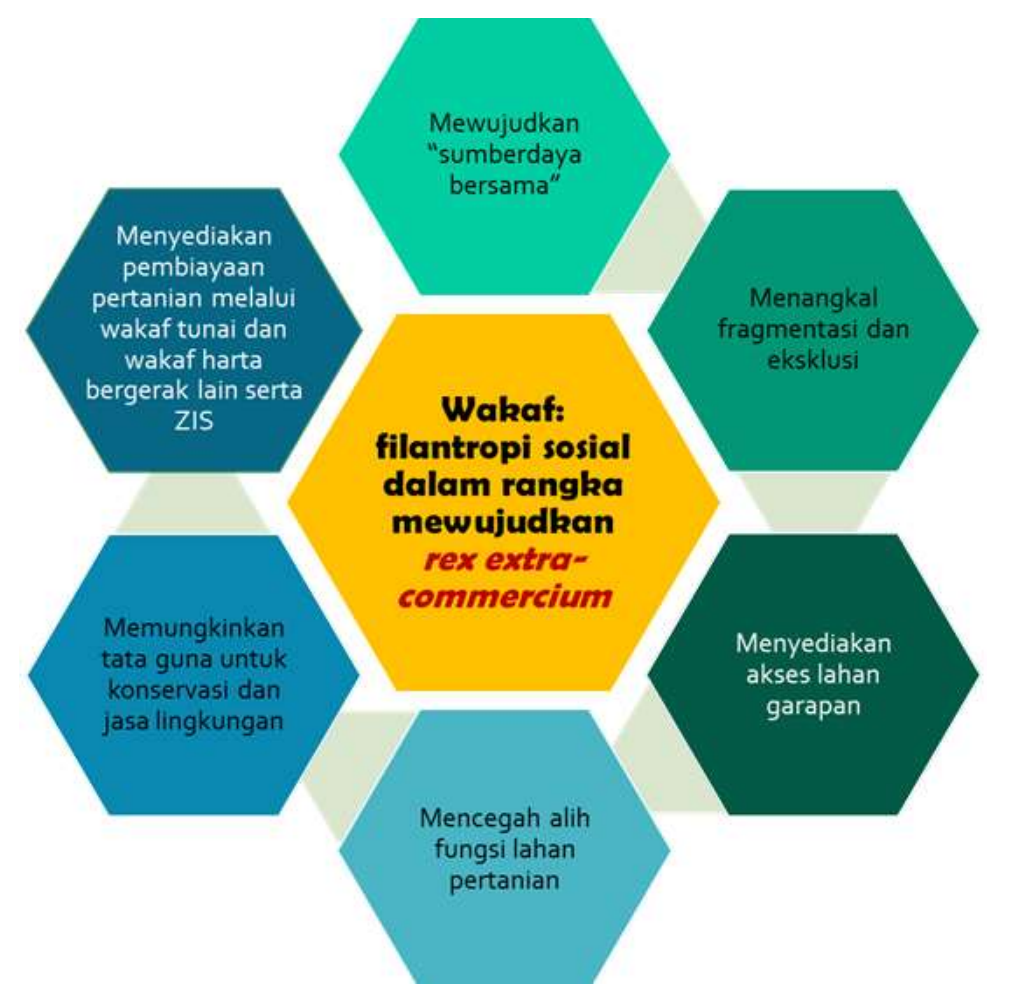

\section{Gambar 3. Signifikansi Wakaf Agraria}

Terkait kenyataan yang pertama, keberadaan harta wakaf sebagai res extra-commercium membuatnya memiliki signifikansi yang sangat relevan dengan agenda perjuangan agraria. Seperti diperlihatkan dalam Gambar 3 di atas, wakaf agraria mampu mewujudkan "sumber daya bersama" (the commons); ia juga dapat menangkal proses eksklusi dan fragmentasi karena harta wakaf tidak boleh diwariskan, dijual atau dialihkan dengan cara apa pun. Selanjutnya, wakaf agraria juga dapat diikrarkan untuk menyediakan akses lahan garapan dalam bentuk hak pakai. Wakaf agraria juga akan memungkinkan penatagunaan tanah wakaf untuk tujuan spesifik, misalnya dengan menetapkan penggunaannya untuk pertanian pangan (dan dengan 
begitu, mencegah konversi lahan pertanian), atau untuk fungsi lindung dan konservasi (misalnya diperuntukkan untuk hutan wakaf). Akhirnya, wakaf agraria juga memungkinkan berbagai peluang pembiayaan pertanian yang dapat diupayakan melalui skema wakaf. Sebagai misal, penggalangan wakaf harta benda bergerak dapat diupayakan untuk penyediaan alat dan mesin pertanian, lalu pembuatan embung dan irigasi juga bisa diupayakan dengan penggalangan wakaf yang lain. Selanjutnya, wakaf tunai dapat digalang untuk penyediaan akses modal usahatani dengan skema pembiayaan syari'ah, dan sebagainya.

Berbagai signifikansi di atas dapat diupayakan karena fleksibilitas wakaf itu sendiri. Seperti telah dijelaskan di atas, beberapa komponen penting wakaf dapat didefinisikan secara spesifik oleh wâqif untuk mewujudkan agenda perjuangan agraria tertentu. Sebagai contoh, terkait peruntukan tanah wakaf, wâqif bisa menetapkan bahwa tujuan pewakafannya bukan untuk mewujudkan sarana "ibadah ritual", namun untuk "ibadah sosial" dalam bentuk penanganan permasalahan agraria tertentu. ${ }^{39}$ Lantas, terkait jenis penggunaan tanah wakaf, wâqif dapat saja menetapkan bahwa tujuan pewakafannya adalah untuk pertanian pangan; hal mana akan membuat tanah wakaf itu sebagai "lahan pertanian pangan abadi" dalam pengertian yang sebenarnya.

Sebagai perbandingan, pemerintah yang memiliki mandat UU Lahan Pertanian Pangan Berkelanjutan masih saja gagal mencegah konversi lahan sawah yang rata-rata mencapai 127 ribu ha per tahun. Tetapi dengan menggunakan skema wakaf ini, sekali tanah diikrarkan untuk wakaf lahan pertanian pangan, maka fungsi tanah ini tidak dapat diubah selamanya. Bahkan jika pemerintah membutuhkan lahan itu untuk kepentingan umum, UU Wakaf menyatakan bahwa hal itu dibolehkan hanya jika sesuai

39 Menurut Pasal 22 UU Wakaf No. 41/2004, wakaf dapat diperuntukkan untuk: (1) sarana kegiatan ibadah; (2) sarana dan kegiatan pendidikan serta kesehatan; (3) bantuan kepada fakir miskin, anak terlantar, yatim piatu, dan bea siswa; (4) kemajuan dan peningkatan ekonomi umat; (5) kemajuan kesejahteraan umum lain yang tidak bertentangan dengan syariah dan peraturan perundang-undangan. Dalam kaitan ini, wakaf agraria dapat dikategorikan ke dalam tujuan peruntukan (4) dan (5) berdasarkan uraian dalam Pasal 22 di atas. 
tata ruang (Pasal 44) serta mendapatkan izin tertulis dari Menteri Agama dan persetujuan dari Badan Wakaf Indonesia. Selain itu, pemerintah juga diharuskan menyediakan tanah pengganti dengan nilai yang sama atau lebih baik (Pasal 41).

Lebih jauh, wâqif juga dapat menentukan apa saja jenis-jenis manfaat yang akan disediakan oleh harta wakaf dan siapa saja penerima manfaatnya. Sebagai misal, hak garap secara bergilir dapat menjadi salah satu manfaat dari tanah wakaf itu, atau hasil panen yang diperoleh dari tanah wakaf itulah yang merupakan manfaatnya. Sementara pihak penerima manfaat dapat dibatasi pada sanak keluarga wâqif sendiri (wakaf ahlî) atau menjangkau pihak-pihak yang lebih luas (wakaf khayrî). Akhirnya, siapa yang dipercaya menjadi nazhîr yang mengelola dan mengembangkan harta benda wakaf itu juga dapat ditentukan oleh wâqif.

Apabila kita mencermati komposisi agenda reforma agraria sendiri, ada tiga komponen pokok yang harus dijalankan, yaitu tata kuasa, tata guna dan tata produksi lahan. Ketiga komponen ini harus diwujudkan untuk memastikan jaminan akses tanah, perlindungan hukum atas akses tanah itu, perlindungan atas daya dukung alam, dan perlindungan atas sistem produksi masyarakat itu sendiri. ${ }^{40}$ Tiga komponen pokok dalam agenda reforma agraria ini ternyata hanya mencerminkan sebagian kecil saja dari sejumlah komponen utama wakaf yang dapat ditetapkan secara langsung oleh wâqif melalui ikrar wakaf. Jadi, alih-alih bersifat kontradiktif terhadap agenda reforma agraria, wakaf justru merupakan skema yang sangat tepat untuk menjalankan agenda reforma agraria ini secara komprehensifsesuatu yang pemerintah sendiri belum berhasil mewujudkannya. ${ }^{41}$

40 Lihat: Mohamad Shohibuddin, Wakaf Agraria, p. 25-27.

41 Pemerintah sering menyatakan bahwa reforma agraria mencakup dua unsur yang tidak dapat dipisahkan satu sama lain, yaitu "land reform" dan "access reform". Unsur yang terakhir ini diartikan sebagai berbagai dukungan pasca penyediaan tanah agar petani dapat berproduksi dengan baik, seperti akses modal, teknologi, pelatihan, pasar, dan sebagainya. Namun, dalam kenyataannya, unsur kedua ini jarang dapat diwujudkan oleh pemerintah, sementara pelaksanaan unsur yang pertama (land reform) sendiri kerap terperangkap pada legalisasi tanah-tanah yang sebenarnya sudah dikuasai oleh rakyat-jadi, bukan (re)distribusi tanah dalam arti yang sebenarnya. 


\section{Konsolidasi Lahan Berbasis Wakaf untuk Pengembangan Korporasi Petani}

Seperti telah penulis elaborasi dalam dua tulisan terpisah, ${ }^{42}$ konsep wakaf agraria ini secara praktis dapat dijalankan melalui setidak-tidaknya sembilan model sebagai berikut: (I) model kontra-fragmentasi; (II) model konsolidasi lahan pertanian skala kecil dan gurem; (III) model donatur utama; (IV) model crowd funding; (V) model pengadaan tanah wakaf desa atas inisiatif pemerintah desa; (VI) model integrasi wakaf dengan inisiatif land reform dari bawah; (VII) model integrasi wakaf dengan program land reform dari pemerintah; (VIII) model konsolidasi lahan perkotaan untuk penataan permukiman rakyat; dan (IX) model mitigasi bencana dan/atau penanganan pasca-bencana

Mengingat keterbatasan ruang, penulis akan menguraikan satu model wakaf agraria saja, yaitu konsolidasi lahan pertanian berbasis wakaf (model II). Dalam model ini, tujuan wakaf adalah untuk menyatukan lahan-lahan pertanian skala kecil dan gurem-yang secara skala ekonomi tidak efisien lagi, dan yang terancam dijual karena berbagai alasan-menjadi satu unit usahatani dengan skala lebih besar sehingga dapat dikelola secara terpadu, efisien dan modern. Model ini bisa diwujudkan dengan pewakafan bersama (joint waqf) oleh para pemilik lahan kecil dan gurem atas lahan mereka yang berada dalam satu hamparan dan saling bersebelahan. Penerima harta wakaf ini adalah lembaga yang mereka dirikan bersama-sama (dapat berupa koperasi, yayasan, badan usaha, serikat tani atau bentuk lainnya) yang sekaligus akan menjadi pengelola (nazhîr) dari tanah wakaf tersebut. Pewakafan ini dapat bersifat berbatas waktu (waqf muaqqat), misalnya 10 tahun saja, atau bisa juga untuk selama-lamanya (waqf muabbad). ${ }^{43}$ Dalam

42 Lihat: Mohamad Shohibuddin, Wakaf Agraria, p. 63-73 dan Mohamad Shohibuddin, "Mempertimbangkan Wakaf," p. 325-329. Untuk mengetahui secara sepintas lalu kesembilan model wakaf ini, silahkan dicermati ringkasannya pada Lampiran 2.

43 Mengenai perbedaan jangka waktu wakaf ini, lihat: Mohamad Shohibuddin, "Wakaf Berjangka untuk Pembaruan Tenurial Skala Desa" dalam Adi D. Bahri dan Mohamad Shohibuddin, ed. Perjuangan Keadilan Agraria: Inspirasi Gunawan Wiradi, (Bogor, Bandung, Jakarta, Yogyakarta: Sajogyo Institute, PSA IPB, Akatiga, Bina Desa, STPN Press, 2020), p. 105-110. 
kedua kasus jangka waktu pewakafan ini, secara tegas harus diikrarkan bahwa para penerima manfaatnya adalah pemilik lahan semula dan/atau para ahli warisnya.

Selain untuk mencegah proses fragmentasi lahan yang pada akhirnya akan berujung pada pelepasan lahan sama sekali, wakaf model konsolidasi ini juga penting untuk merespons program korporasi petani yang sedang dikembangkan oleh Kementerian Pertanian. Saat ini Rancangan Peraturan Presiden (Raperpres) tentang korporasi petani bahkan sedang digodok pemerintah. Sayangnya, apa yang pemerintah bayangkan tentang konsep ini adalah sebatas pengembangan korporasi berbasis komoditas unggulan yang justru sangat bias kepentingan petani kaya dan pengusaha. Apabila pendekatan inilah yang nanti dituangkan ke dalam Raperpres, maka nasib petani kecil/gurem dengan lahan di bawah 2 ha akan kian termarginalkan. Hal ini hanya akan mengulang kembali kisah exclusion by programme seperti terjadi saat pelaksanaan kebijakan Revolusi Hijau di masa Orde Baru yang ternyata lebih menguntungkan kepentingan petani kaya dan elite desa.

Korporasi petani berbasis wakaf dengan model konsolidasi ini dapat dijadikan sebagai solusi karena ia dilandaskan pada kepentingan petani skala kecil dan gurem. Melalui mekanisme pewakafan bersama oleh para petani marginal ini, maka akan terhimpun bentangan lahan sawah yang cukup luas (misalnya: 5 ha, 7 ha, 10 ha atau 15 ha) yang berada dalam satu hamparan dan dapat dikelola sebagai satu kesatuan usahatani. Hal ini akan mengatasi persoalan kronis ketersediaan lahan petani yang sering dikeluhkan para perancang kebijakan "korporasi petani". Dari sini, maka dimungkinkan untuk mengembangkan program "korporasi petani" yang melibatkan dukungan pemerintah dan partisipasi sektor swasta. Bedanya dari pendekatan konvensional adalah: korporasi dengan model wakaf ini berbasis pada petani marginal itu sendiri dan peduli pada kepentingan mereka. Jadi, berbeda dari model korporasi petani yang lebih mewakili kepentingan para petani kaya dan elite desa maupun kepentingan pemilik 
Satu catatan penting perlu disajikan di sini untuk menutup uraian mengenai wakaf agraria. Kendati wakaf adalah skema yang berdasarkan hukum Islam, namun tidak berarti bahwa pelaku wakaf atau penerima manfaatnya terbatas untuk umat Islam semata. Selama wakaf itu tidak ditujukan untuk sarana dan prasarana peribadatan Islam (seperti masjid, mushala, pemakaman Muslim dan sejenisnya), melainkan ditujukan untuk pemberdayaan sosial-ekonomi bagi masyarakat secara luas, maka wakaf merupakan skema yang sepenuhnya bersifat inklusif. Dengan kata lain, wakaf dengan tujuan yang mencerminkan nilai-nilai kebajikan universal (al-birr) terbuka untuk dilakukan oleh seorang non-Muslim; demikian juga, manfaatnya dapat diberikan kepada kalangan non-Muslim. ${ }^{45} \mathrm{Hal}$ inilah yang membedakan skema wakaf ini dari zakat di mana baik pelaku maupun penerimanya terbatas pada kalangan umat Islam semata.

\section{Simpulan}

Berdasarkan kerangka teoritis seputar “dialektika akses dan eksklusi” serta implikasinya pada perjuangan akses dan kontra-eksklusi, artikel ini telah memperlihatkan bagaimana Islam Nusantara ternyata telah terlibat dalam merespons pergulatan agraria yang dialami masyarakat sebagai perwujudan

44 Sebenarnya, korporasi petani berbasis wakaf yang berasal dari hasil konsolidasi lahan skala kecil dan gurem ini (model II) adalah satu model saja yang dapat dikembangkan. Masih ada tujuh model lain yang dapat dikembangkan, yaitu dengan menyasar: lahan yang diwakafkan dalam rangka mencegah fragmentasi (model 1); lahan yang diwakafkan oleh donatur utama (model III); lahan wakaf yang diperoleh dari penggalangan crowd funding (model IV); lahan wakaf desa yang diwujudkan melalui inisiatif pemerintah desa (model V dengan dua skema); lahan hasil pewakafan bersama atau pewakafan lahan kolektif yang sumbernya berasal dari inisiatif land reform dari bawah (model VI) atau dari program land reform pemerintah (model VII); dan lahan hasil pewakafan bersama di lokasi rawan bencana atau terdampak bencana (model IX).

Secara ringkas, uraian mengenai pengembangan korporasi petani berbasis wakaf melalui kesemua model di atas dapat dicermati pada Lampiran 3.

45 Lihat: Muhammad Abu Zahrah, Muhâdlarât fî al-Waqf, (tanpa tempat terbit: Ahmad 'Ali Mukhaymar, 1959), p. 97-98. Meskipun demikian, UU Wakaf menyatakan bahwa saksi dalam ikrar wakaf dan nazhîr yang mengelola harta benda wakaf tetap disyaratkan harus beragama Islam. Hal ini untuk memastikan bahwa peruntukan dan pengelolaan harta benda wakaf tidak melanggar ketentuan hukum Islam. Namun, dalam hal pelaku wakaf dan penerima manfaatnya, tidak ada persyaratan harus beragama Islam. 
dari dua agenda pokoknya: pribumisasi dan transformasi. Keterlibatan ini ditunjukkan melalui bagaimana pergulatan dalam merespons "tantangan akses" dan "ancaman eksklusi" tercermin dengan cukup menonjol dalam berbagai artikulasi Islam Nusantara, mulai dari level keluarga hingga level relasi sosio-agraria yang lebih luas di ranah masyarakat. Selain itu, artikel ini secara khusus juga mengulas ijtihad agraria yang dikeluarkan NU, termasuk menjernihkan berbagai isu kontroversial mengenai hubungan NU dan land reform. Akhirnya, artikel ini juga mengusulkan pengembangan wakaf agraria sebagai skema alternatif dalam mewujudkan agenda perjuangan agraria, dan sekaligus diajukan sebagai sebuah terobosan baru ijtihad agraria Islam Nusantara.

Terobosan baru semacam wakaf agraria ini penting untuk digali dan dikembangkan mengingat salah satu masalah genting yang terjadi di Indonesia dewasa ini adalah makin menajamnya kondisi ketimpangan agraria. Hal ini terjadi baik menyangkut ketimpangan dalam "distribusi lahan" diantarasesamapetanisendirimaupunketimpangandalamkebijakan "alokasi lahan" dari pemerintah antara yang diberikan kepada korporasi besar dan yang disediakan untuk rakyat. ${ }^{46} \mathrm{Hal}$ yang mencengangkan adalah bahwa tingkat ketimpangan agraria yang terjadi selama dua dekade terakhir di bawah rezim reformasi ini ternyata telah jauh melampaui kondisi yang terjadi selama tiga dekade di bawah rezim Orde Baru.

Sebagai misal, berdasarkan data yang dikeluarkan Lembaga Penjamin Nasabah (hingga Oktober 2017), 56,87\% simpanan uang di lembaga perbankan nasional dikuasai oleh hanya $0,11 \%$ pemilik "rekening gendut" dengan nilai tabungan di atas Rp 2 miliar. ${ }^{47}$ Akumulasi kekayaan semacam ini diduga berkaitan erat dengan kondisi satu dekade sebelumnya (2007) di mana, dengan proporsi yang hampir sama, 56\% aset agraria nasional

46 Mengenai dua jenis ketimpangan agraria ini dan bagaimana kondisinya di Indonesia saat ini, lihat penjelasannya dalam Mohamad Shohibuddin, Ketimpangan Agraria di Indonesia.

47 Data ini disajikan dalam Megawati Institute, Hasil Riset Oligarki Ekonomi, (Jakarta: Megawati Institute, 2017). 
dikuasai oleh hanya $0,25 \%$ penduduk Indonesia ${ }^{48}$ Ketimpangan yang sangat njomplang semacam ini tentu bertentangan dengan spirit dasar gerakan reformasi itu sendiri untuk mewujudkan demokratisasi di bidang ekonomi (bukan hanya politik), dan terutama sekali juga mengingkari cita-cita dasar kemerdekaan negara kita seperti termaktub dalam pembukaan UUD 1945.

Kenyataan ironis ini tentu harus menjadi kepedulian utama dalam pengembangan wacana dan praktik Islam Nusantara di masa depan. Mengabaikan kenyataan struktural ini bukan saja merupakan pengingkaran atas peran penting Islam Nusantara di lapangan agraria, seperti diuraikan di sepanjang paparan artikel ini. Lebih jauh lagi, pengabaian itu juga akan melalaikan agenda Islam Nusantara yang kedua, yakni transformasi. Jika hal ini terjadi, Islam Nusantara akan kehilangan relevansi sosial, ekonomi dan politiknya di tengah-tengah masyarakat. Akibatnya, berbagai klaim keunggulan Islam Nusantara sebagaimana sering disuarakan selama ini akan menjadi jargon kosong belaka. []

48 Lihat: Joyo Winoto, "Reforma Agraria: Mandat Politik, Konstitusi dan Hukum dalam Rangka Mewujudkan Tanah untuk Keadilan dan Kesejahteraan Rakyat." Kuliah Umum disampaikan di Balai Senat Universitas Gadjah Mada, Yogyakarta, 22 November 2007. 


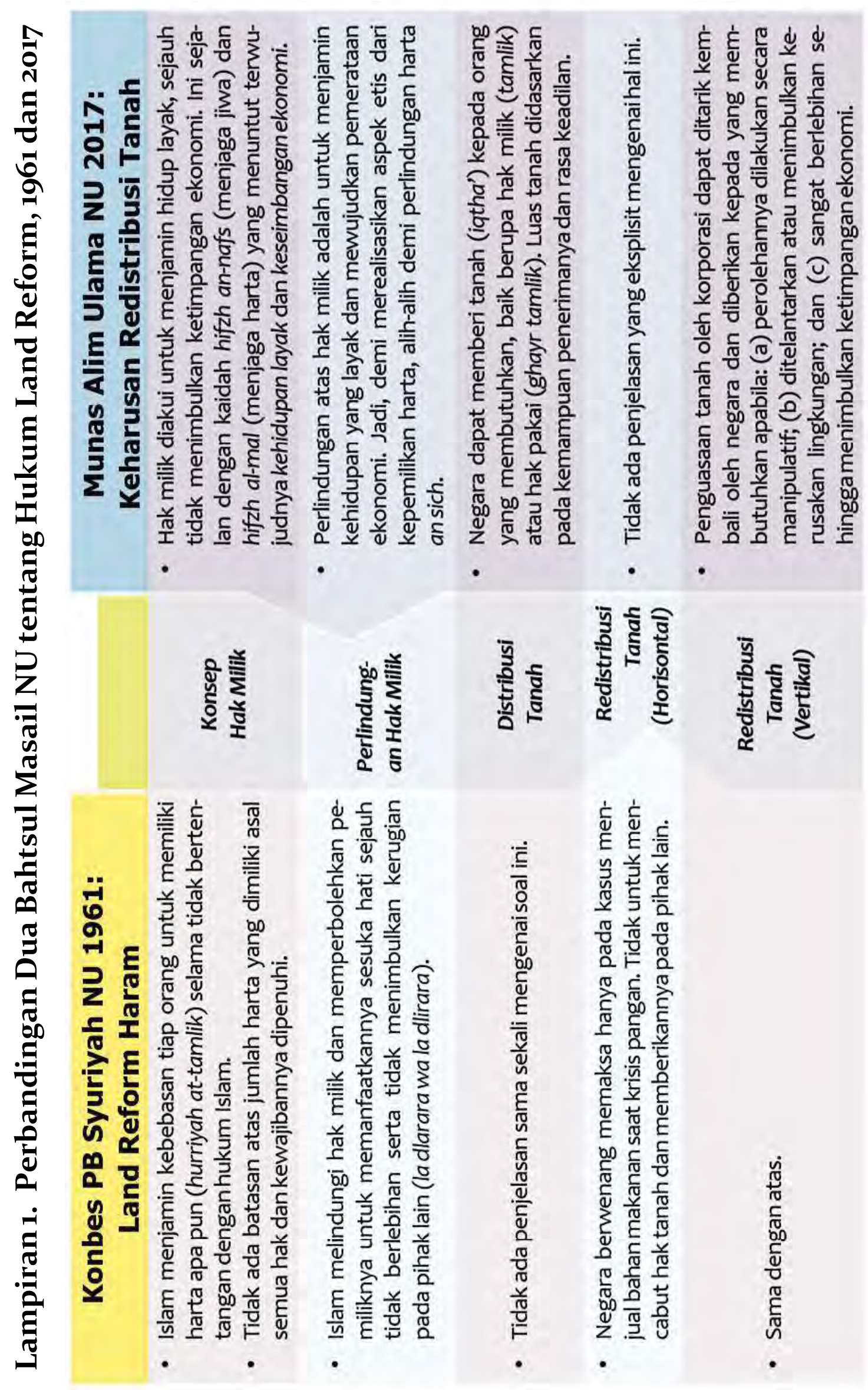




\section{Lampiran 2. Sembilan Model Wakaf Agraria}

\begin{tabular}{|c|c|c|}
\hline Model & Potensi Tanah untuk Diwakafkan & Penerima Manfaat \\
\hline $\begin{array}{l}\text { 1. Kontra- } \\
\text { fragmentasi }\end{array}$ & $\begin{array}{l}\text { Tanah pertanian di bawah batas } \\
\text { maksimum penguasaan lahan yang } \\
\text { terancam mengalami fragmentasi karena } \\
\text { proses pewarisan }\end{array}$ & $\begin{array}{l}\text { Para ahli waris yang } \\
\text { membutuhkan (wakaf } \\
\text { ahlî) }\end{array}$ \\
\hline $\begin{array}{l}\text { 2. Konsolidasi } \\
\text { lahan } \\
\text { pertanian }\end{array}$ & $\begin{array}{l}\text { Tanah pertanian kurang dari } 2 \text { ha yang } \\
\text { diwakafkan secara bersama oleh para } \\
\text { pemiliknya kepada lembaga yang mereka } \\
\text { bentuk bersama untuk diusahakan pada } \\
\text { skala yang lebih efisien }\end{array}$ & $\begin{array}{l}\text { Para pemilik tanah } \\
\text { semula dan ahli waris } \\
\text { masing-masing }\end{array}$ \\
\hline $\begin{array}{l}\text { 3. Donatur } \\
\text { utama }\end{array}$ & $\begin{array}{l}\text { Pewakafan tanah pertanian milik sendiri } \\
\text { atau pembelian tanah pertanian skala } \\
\text { kecil dan gurem untuk diwakafkan } \\
\text { dengan model konsolidasi }\end{array}$ & $\begin{array}{l}\text { Petani miskin setempat } \\
\text { atau para pemilik tanah } \\
\text { semula jika tanah dibeli } \\
\text { dari mereka }\end{array}$ \\
\hline $\begin{array}{l}\text { 4. Crowd } \\
\text { funding }\end{array}$ & $\begin{array}{l}\text { Penggalangan dana dari masyarakat oleh } \\
\text { pihak pemrakarsa untuk dibelikan tanah } \\
\text { pertanian skala kecil dan gurem untuk } \\
\text { diwakafkan dengan model konsolidasi } \\
\text { atau pengadaan tanah wakaf baru }\end{array}$ & $\begin{array}{l}\text { Petani miskin setempat } \\
\text { atau para pemilik tanah } \\
\text { semula }\end{array}$ \\
\hline $\begin{array}{l}\text { 5. Tanah wakaf } \\
\text { desa }\end{array}$ & $\begin{array}{l}\text { Pengadaan tanah wakaf oleh pemerintah } \\
\text { desa yang berasal dari sumberdaya desa } \\
\text { sendiri maupun dengan penggalangan } \\
\text { donasi }\end{array}$ & $\begin{array}{l}\text { Warga desa yang } \\
\text { miskin } \\
\text { membutuhkan }\end{array}$ \\
\hline $\begin{array}{l}\text { 6. Integrasi } \\
\text { dengan land } \\
\text { reform by } \\
\text { leverage }\end{array}$ & $\begin{array}{l}\text { Pewakafan tanah secara bersama atau } \\
\text { alokasi tanah kolektif untuk diwakafkan } \\
\text { yang diperoleh dari aksi land reform by } \\
\text { leverage oleh serikat tani }\end{array}$ & $\begin{array}{l}\text { Petani miskin setempat } \\
\text { yang membutuhkan } \\
\text { dan anggota serikat } \\
\text { tani secara umum }\end{array}$ \\
\hline $\begin{array}{l}\text { 7. Integrasi } \\
\text { dengan land } \\
\text { reform } \\
\text { pemerintah }\end{array}$ & $\begin{array}{l}\text { Pewakafan tanah secara bersama atau } \\
\text { alokasi tanah kolektif untuk diwakafkan } \\
\text { yang diperoleh dari program land reform } \\
\text { yang dilaksanakan pemerintah }\end{array}$ & $\begin{array}{l}\text { Petani miskin setempat } \\
\text { yang membutuhkan } \\
\text { dan anggota serikat } \\
\text { tani secara umum }\end{array}$ \\
\hline $\begin{array}{l}\text { 8. Konsolidasi } \\
\text { lahan } \\
\text { perkotaan }\end{array}$ & $\begin{array}{l}\text { Pewakafan secara bersama tanah-tanah } \\
\text { di kawasan kumuh untuk dikonsolidasikan } \\
\text { dalam rangka penataan permukiman }\end{array}$ & $\begin{array}{l}\text { Para pemilik tanah } \\
\text { semula dan ahli waris } \\
\text { masing-masing }\end{array}$ \\
\hline $\begin{array}{l}\text { 9. Mitigasi } \\
\text { bencana/ } \\
\text { penanganan } \\
\text { pasca- } \\
\text { bencana }\end{array}$ & $\begin{array}{l}\text { Pewakafan secara bersama atas tanah di } \\
\text { lokasi rawan bencana atau terdampak } \\
\text { bencana untuk dikonsolidasikan dalam } \\
\text { rangka penataan kawasan yang sensitif } \\
\text { bencana dan memberi manfaat ekonomi }\end{array}$ & $\begin{array}{l}\text { Para pemilik tanah } \\
\text { semula dan ahli waris } \\
\text { masing-masing }\end{array}$ \\
\hline
\end{tabular}




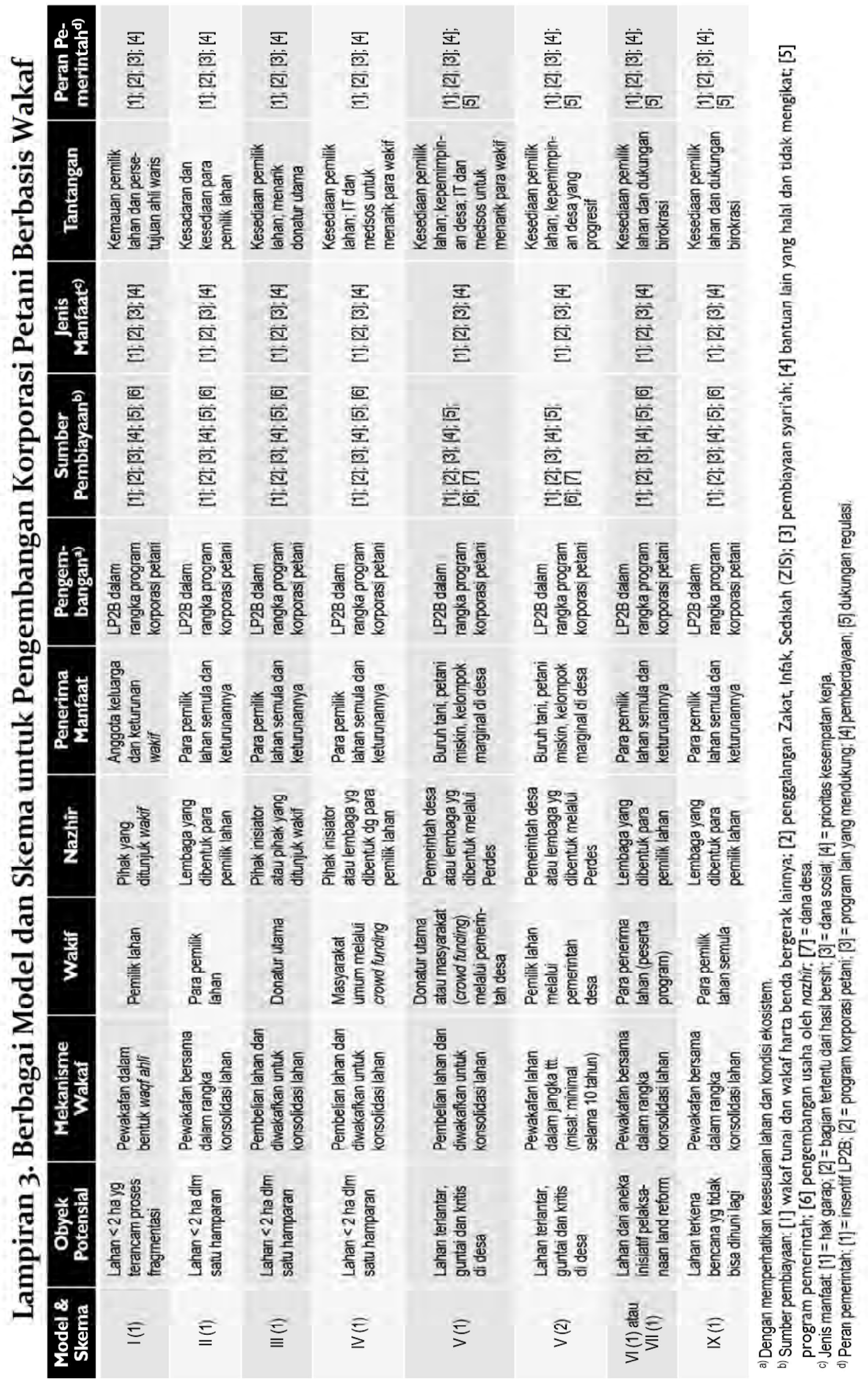




\section{Daftar Pustaka}

Abbasi, Muhammad Zubair, "The Classical Islamic Law of Waqf: A Concise Introduction." Arab Law Quarterly 26, No. 2 (2012): p. 121-153.

Abu Zahrah, Muhammad, Muhâdlarât fî al-Waqf. Tanpa tempat terbit: Ahmad 'Ali Mukhaymar, 1959.

Hall, Derek, Philip Hirsch, Tania Murray Li, Powers of Exclusion: Land Dilemmas in Southeast Asia. Singapore: NUS Press, 2011.

Ibrahim, Bilal, "Beyond State and Peasant: The Egalitarian Import of Juristic Revisions of Agrarian and Administrative Contracts in the Early Mamlūk Period." Islamic Law and Society 16, No. 3-4 (2009): p. 337-382.

Johansen, Baber, The Islamic Law on Land Tax and Rent: The Peasants' Loss of Property Rights as Interpreted in the Hanafite Legal Literature of the Mamluk and Ottoman Periods. London, New York, Sydney: Croom Helm, 1988.

Lembaga Ta’lif wan Nasyr PWNU Jawa Timur, Ahkamul Fuqaha: Solusi Problematika Aktual Hukum Islam. Keputusan Muktamar, Munas dan Konbes Nahdlatul Ulama (1926-2004). Surabaya: Khalista, 2007.

Luthfi, Ahmad Nashih, "Sejarah dan Revitalisasi Perjuangan Pertanian Nahdlatul Ulama Melawan Ketidakadilan Agraria." Bhumi: Jurnal Agraria Dan Pertanahan 3, No. 2 (2017): p. 145-159.

Megawati Institute, Hasil Riset Oligarki Ekonomi. Jakarta: Megawati Institute, 2017. 
Powers, David S., "Orientalism, Colonialism, and Legal History: The Attack on Muslim Family Endowments in Algeria and India." Comparative Studies in Society and History 31, No. 3 (1989): p. 535-571.

Ribot, Jesse C. and Nancy Lee Peluso, "A Theory of Access." Rural Sociology 68 No. 2 (2003): p. 153-181.

Shohibuddin, Mohamad, Eko Cahyono, Adi Dzikrullah Bahri, "UndangUndang Desa dan Isu Sumber Daya Alam: Peluang Akses atau Ancaman Eksklusi?" Wacana 19, No. 36 (2017): p. 29-81. Tersedia melalui tautan berikut ini: http://ipb.link/desa-dan-agraria.

Shohibuddin, Mohamad, Ahmad Nashih Luthfi, Westi Utami, ed. Meninjau Ulang Pengaturan Hak Adat. Yogyakarta dan Bogor: STPN Press dan Pusat Studi Agraria IPB, 2019. Bisa diunduh melalui tautan berikut: http://bit.ly/36pdY5e.

Shohibuddin, Mohamad dan Adi D. Bahri, ed. Perjuangan Keadilan Agraria. Yogyakarta, Bogor, Jakarta dan Bandung: Insist Press bekerja sama dengan Sajogyo Institute, Bina Desa dan Akatiga, 2019. Pengantar penyunting dapat dilihat melalui tautan ini: http://bit.ly/2QR2jaK.

Shohibuddin, Mohamad, "Dua Wajah Islam Nusantara." Koran Sindo, 11 April 2017. Versi lebih panjang dapat dilihat pada tautan ini: https:// www.facebook.com/notes/mohamad-shohibuddin/dua-wajah-islamnusantara/10155013669631224.

--------, Perspektif Agraria Kritis: Teori, Kebijakan dan Kajian Empiris. Yogyakarta: STPN Press, PSA IPB, Sajogyo Institute dan KPA, 2018. Bisa diunduh melalui tautan berikut ini: http://ipb.link/perspektif-agraria.

-------, Wakaf Agraria: Signifikansi Wakaf Bagi Agenda Reforma Agraria. Yogyakarta dan Bogor: Baitul Hikmah, Magnum Pustaka Utama dan Sajogyo Institute, 2019. Beberapa review buku ini bisa dilihat pada tautan ini: $\underline{\text { http://bit.ly/2NLwyxp. }}$ 
------, "Mempertimbangkan Wakaf Sebagai Skema Alternatif Pelaksanaan Tenure Reform." Dalam Mohamad Shohibuddin dan Adi D. Bahri, ed. Perjuangan Keadilan Agraria. Yogyakarta, Bogor, Jakarta dan Bandung: Insist Press bekerja sama dengan Sajogyo Institute, Bina Desa dan Akatiga, 2019. Bab ini bisa diunduh melalui tautan berikut ini: http://bit.ly/2PI0omw.

--------, "Wakaf Berjangka untuk Pembaruan Tenurial Skala Desa." Dalam Adi D. Bahri dan Mohamad Shohibuddin, ed. Perjuangan Keadilan Agraria: Inspirasi Gunawan Wiradi. Bogor, Bandung, Jakarta, Yogyakarta: Sajogyo Institute, PSA IPB, Akatiga, Bina Desa, STPN Press, 2020. Bisa diunduh melalui tautan ini: https://ipb.link/wakaf-berjangka.

--------, Ketimpangan Agraria di Indonesia: Pendekatan Studi, Kondisi Terkini dan Kebijakan Penanganan. Bogor: IPB Press, 2020. Versi e-book dapat diperoleh melalui tautan berikut ini: http://bit.ly/ BukuKetimpanganAgraria.

Winoto, Joyo, "Reforma Agraria: Mandat Politik, Konstitusi dan Hukum dalam Rangka Mewujudkan Tanah untuk Keadilan dan Kesejahteraan Rakyat." Kuliah Umum disampaikan di Balai Senat Universitas Gadjah Mada, Yogyakarta pada 22 November 2007. 


\section{Author Guideline}

SLAM NUSANTARA: Journal for Study of History and Culture
is a multidisciplinary journal for scholars who have a concern about
Islamic studies and Indonesia studies focusing on education, thoughts, philosophy, history, law, politics, economy, anthropology and sociology.

ISLAM NUSANTARA: Journal for Study of History and Culture is a peer-reviewed journal that is published twice a year in June and December by Faculty of Islam Nusantara University of Nahdlatul Ulama Indonesia (UNUSIA) Jakarta.

Papers submitted for publication must conform to the following guidelines:

1. Papers must be typed in one-half spaced on A4-paper size;

2. Papers' length is about $6,000-10,000$ words;

3. All submission must include a 200-300 word abstract;

4. Full name(s) of the author(s) must be stated, along with his/her/ 
their institution and complete e-mail address;

5. All submission should be in OpenOffice, Microsoft Word, RTF, or WordPerfect document file format;

6. Arabic words should be transliterated according to the style of 'Islam Nusantarad Studies';

7. Bibliographical reference must be noted in footnote and bibliography according to 'Islam Nusantarad Studies' style.

\section{Examples of footnote style:}

${ }^{1}$ Ryan Sugiarto, Psikologi Raos: Saintifikasi Kawruh Jiwa Ki Ageng Suryomentaram, (Yogyakarta: Pustaka Ifada, 2015), p. 139.

${ }^{2}$ Nur Syam, Tarekat Petani: Fenomena Tarekat Syattariyah Lokal, (Yogyakarta: LkiS, 2013), h. 164.

${ }^{3}$ Syam, Tarekat Petani, p. 173.

${ }^{4}$ Ubaidillah Achmad dan Yuliyatun Tajuddin, Suluk Kiai Cebolek Dalam Konflik Keberagamaan dan Kearifan Lokal, (Jakarta: Prenada, 2014), p. 140.

${ }^{5}$ Nur Syam, Tarekat Petani, p. 99.

${ }^{6} \mathrm{M}$. Quraish Shihab, Tafsir Al-Misbah, vol. 14 (Bandung: Lentera Hati, 2013), p. 167.

${ }^{7}$ Deny Hamdani, "Cultural System of Cirebonese People: Tradition of Maulidan in the Kanoman Kraton," Indonesian Journal of Social Sciences 4, no. 1 (January-June 2012): p.12.

${ }^{8}$ Hamdani, “Cultural System of Cirebonese People," p. 14.

${ }^{9}$ Deny Hamdani, "Raison de'etre of Islam Nusantara," The Jakarta Post, 06 Agustus 2015, p. 5. 
${ }^{10}$ Azyumardi Azra, "Islam di "Negeri Bawah Angin" dalam Masa Perdagangan," Studia Islamika 3, no. 2 (1996): h. 191-221, review buku Anthony Reid, Southeast Asia in the Age of Commerce (New Haven: Yale University Press, 1988).

\section{Example of Bibliography}

Bizawie, Zainul Milal. Masterpiece Islam Nusantara: Sanad dan Jejaring Ulama-Santri (1830-1945). Tangerang: Pustaka Compass, 2016).

Madjid, M. Dien dan Wahyudi, Johan. Ilmu Sejarah: Sebuah Pengantar. Jakarta: Prenada Media Group, 2014.

Banawiratma, JB. dkk., Dialog Antarumat Beragama: Gagasan dan Praktik di Indonesia. Bandung: Mizan Media Utama, 2010.

Sejarah Melayu/Malay Annals. Kuala Lumpur, Oxford University Press, 1970.

Tim Forza Pesantren. Ijtihad Politik Islam Nusantara:Membumikan Fiqih Siyasah Melalui Pendekatan Maqasid asy-Syariah. Kediri, Lirboyo Press, 2015.

Mastuki dan El-Saha, M. Ishom, ed. Intelektualisme Pesantren:Potret Tokoh dan Cakrawala Pemikiran di Era Pertumbuhan Pesantren. Jakarta: Diva Pustaka, 2003.

Suriasumantri, Jujun S. Ilmu Dalam Perspektif: Sebuah Kumpulan Karangan Tentang Hakekat Ilmu, Cet. XII. Jakarta: Yayasan Pustaka Obor Indonesia, 2012.

Simuh. Sufisme Jawa : transformasi tasawuf Islam ke mistik Jawa. Yogyakarta: Yayasan Bentang Budaya, 1995. Reprint, Yogyakarta: Narasi, 2016. 
Muhajir, Afifuddin, "Islam Nusantara untuk Peradaban Indonesia dan Dunia." Dalam Akhmad Sahal dan Munawir Aziz, ed. Islam Nusantara: Dari Ushul Fiqh Hingga Konsep Historis. Bandung: Mizan Pustaka, 2015.

Islam, Adib Misbahul. "Nazam Tarekat: Perlawanan Kiai Ahmad arRifa'i terhadap Birokrasi." Dalam Islam Nusantara Past and Present:Proceeding of International Conference on Islam Nusantara (ICON) 2014. Jakarta: Pusmabit, 2014: h. 55-73.

Affan, Heyder. "Polemik di balik istiIah 'Islam Nusantara." Artikel diakses pada 22 Juni 2015 dari http://www.bbc.com/indonesia/berita indonesia/2015/06/150614_indonesia_islam_nusantara

Malikov, Azim. "Islam: Saints and Sacred Geographies." Dalam Suad Joseph, ed. Encyclopedia of Women and Islamic Cultures, vol. V. Leiden: Brill, 2007: h. 223-225.

Hamdani, Deny. "Raison de'etre of Islam Nusantara." The Jakarta Post, 06 Agustus 2015.

"Batunaga, Bagian dari situs lebih luas," Pikiran Rakyat, 16 Mei 2014.

Hamdani, Deny. "Cultural System of Cirebonese People: Tradition of Maulidan in the Kanoman Kraton." Indonesian Journal of Social Sciences 4, no. 1 (January-June 2012): h.12.

Hosen, Nadirsyah. "Islam Nusantara: Islam Lokal yang Menuju Islam Global?” Gatra, 2 Maret 2016, h. 60.

El-Mawa, Mahrus. "Syattariyah wa Muhammadiyah: Suntingan Teks, Terjemahan dan Analisis Karakteristik Syatariyah di Keraton Kaprabonan Cirebon Pada Akhir Abad ke-19." Disertasi S3 Fakultas Ilmu Pengetahuan Budaya, Universitas Indonesia, 2015.

Azra, Azyumardi. "Islam di "Negeri Bawah Angin" dalam Masa 
Perdagangan." Studia Islamika 3, no. 2 (1996): h. 191-221. Review buku Anthony Reid, Southeast Asia in the Age of Commerce. New Haven: Yale University Press, 1988.

Taimiyya, Ibnu. Minhaj as-Sunnah an-Nabawiy. T.tp.: Darul Urubiyya, 1962.

Dawud, Abu. Sunan. Kairo: T.pn., 1951.

Bajuri, Ibrahim. Hasyiah al-Bajuri ala Matn al-Burdah. Bandung: Darul Ma’arif, t.t.

\section{GUIDELINES FOR BOOK REVIEWS}

1. Please include, at the beginning of the review:

Author, Title, Place, Publisher, Date, number of pages, ISBN E.g., Turabian, Kate L. A Manual for Writers of Term Papers, Theses, and Dissertations. Sixth edition. Chicago and London: University of Chicago Press, 1996. $308+$ ix pp. ISBN: 0-226-81627-3.

2. The review should begin with a brief overall description of the book.

3. Matters that may be considered in the body of the review include:

4. The average review should be about 1500 words long. The name, affiliation and email address of the reviewer should appear at the end of the review.

The strengths and weaknesses of the book.

Comments on the author's style and presentation.

Whether or not the author's aims have been met.

Errors (typographical or other) and usefulness of indices.

Who would the book be useful to?

Would you recommend it for purchase?

5. The preferred format for submissions is MS-Word. 


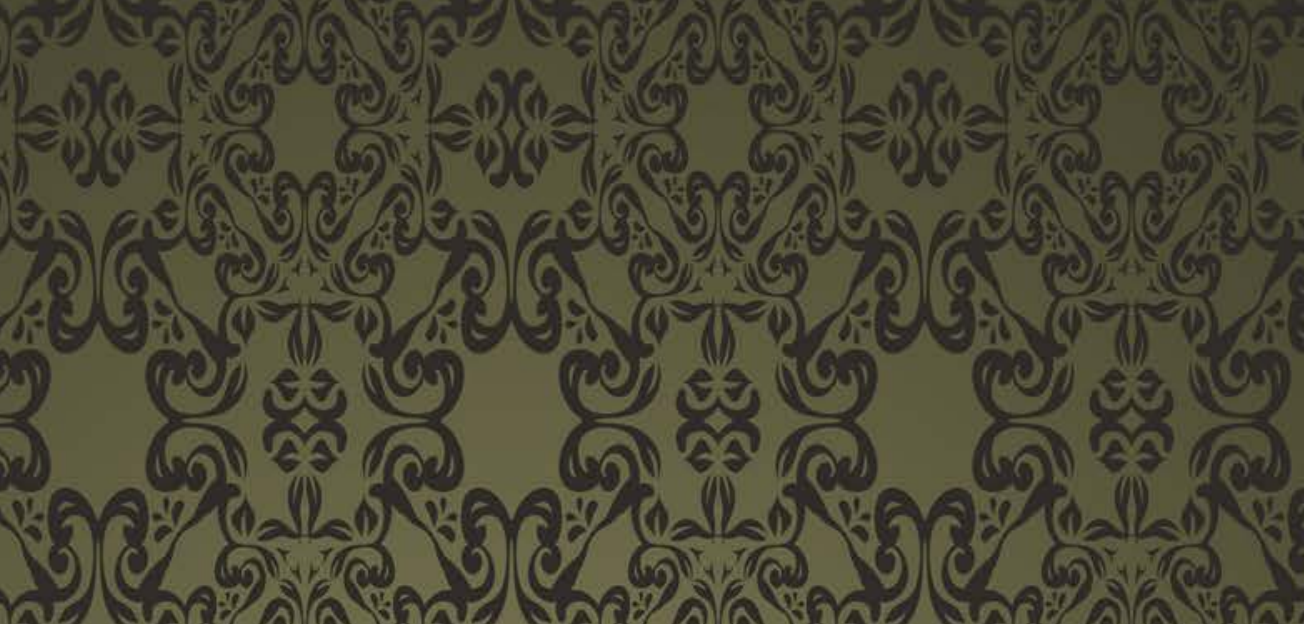

(2.)

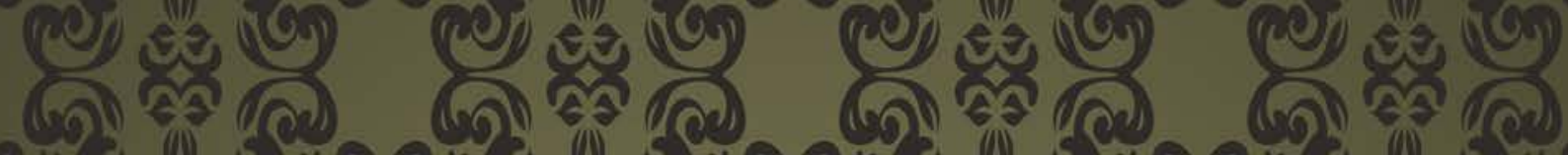

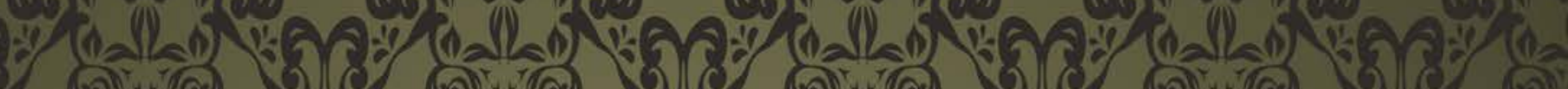

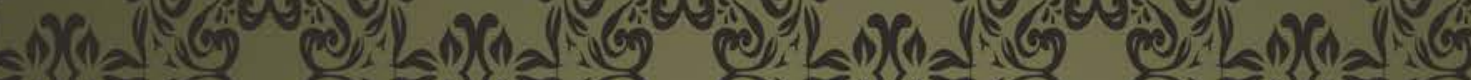

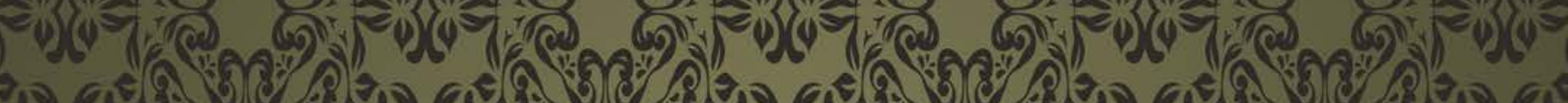

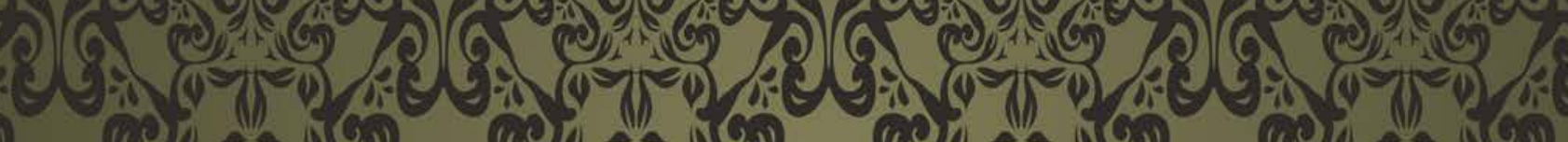

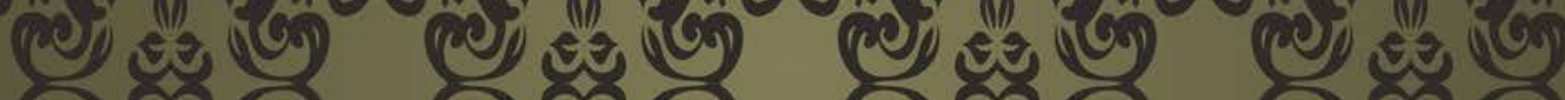

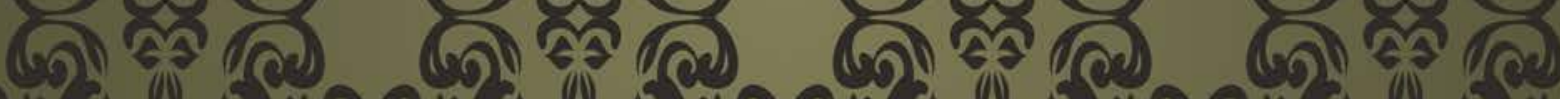
(8):-

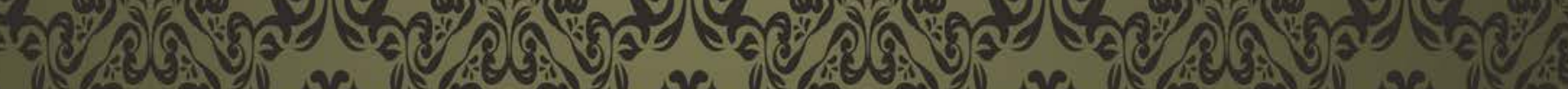

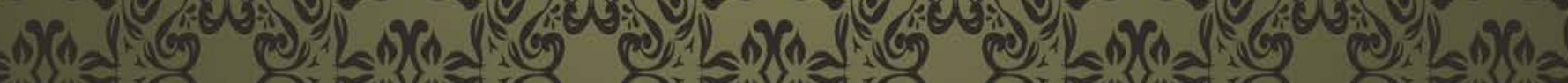

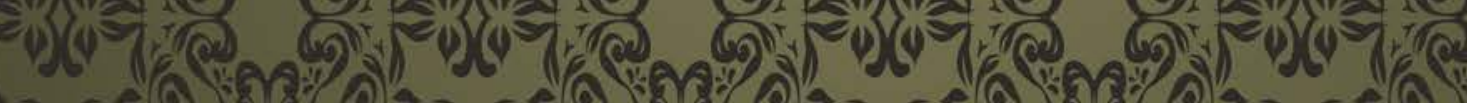
9) (a) (3)

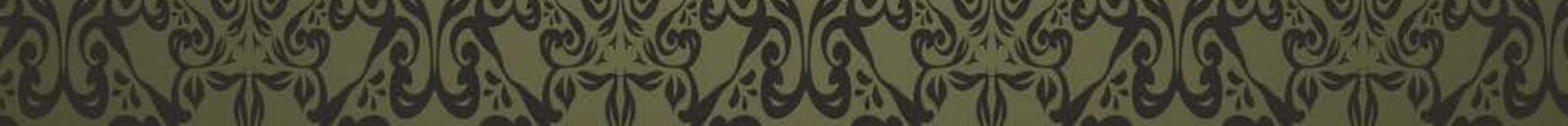

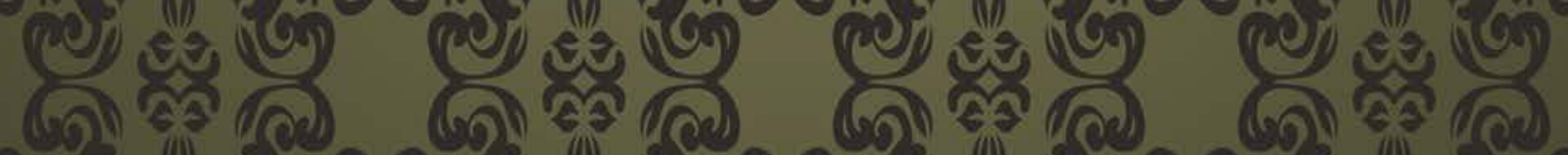

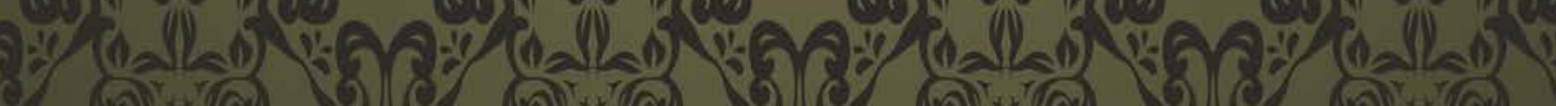

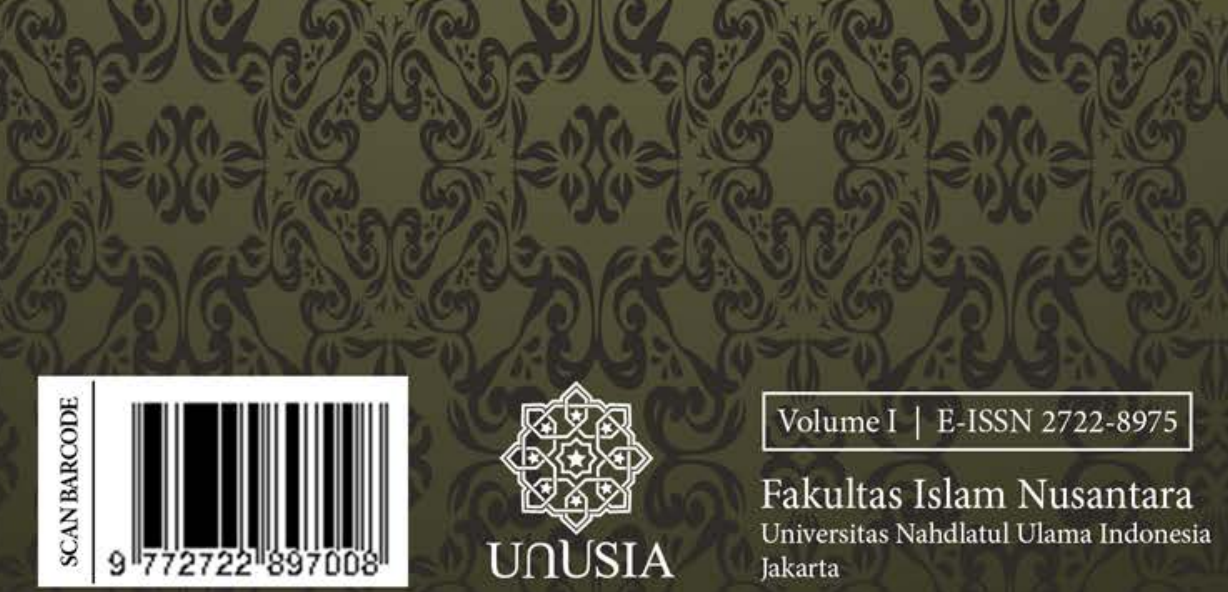

